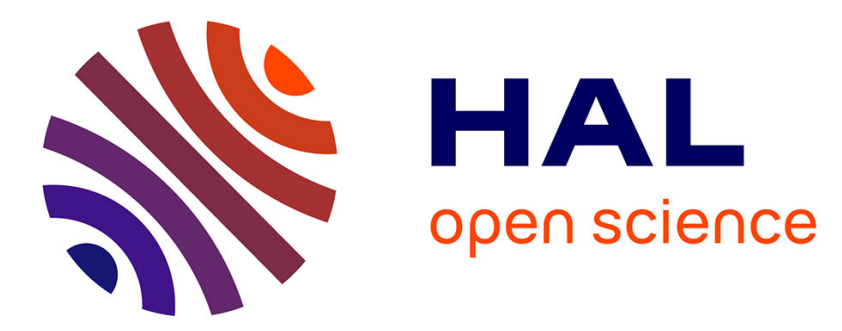

\title{
New imaging of the salinity crisis: Dual Messinian lowstand megasequences recorded in the deep basin of both the eastern and western Mediterranean
}

Christian Gorini, Lucien Montadert, Marina Rabineau

\section{- To cite this version:}

Christian Gorini, Lucien Montadert, Marina Rabineau. New imaging of the salinity crisis: Dual Messinian lowstand megasequences recorded in the deep basin of both the eastern and western Mediterranean. Marine and Petroleum Geology, 2015, 66 (Part 1), pp.278-294. 10.1016/j.marpetgeo.2015.01.009 . hal-01117137

\section{HAL Id: hal-01117137 https://hal.sorbonne-universite.fr/hal-01117137}

Submitted on 16 Feb 2015

HAL is a multi-disciplinary open access archive for the deposit and dissemination of scientific research documents, whether they are published or not. The documents may come from teaching and research institutions in France or abroad, or from public or private research centers.
L'archive ouverte pluridisciplinaire HAL, est destinée au dépôt et à la diffusion de documents scientifiques de niveau recherche, publiés ou non, émanant des établissements d'enseignement et de recherche français ou étrangers, des laboratoires publics ou privés. 
New imaging of the salinity crisis: Dual Messinian lowstand megasequences recorded in the deep basin of both the eastern and western Mediterranean

Christian Gorini $^{1-2}$, Lucien Montadert ${ }^{3}$, Marina Rabineau ${ }^{4}$

(1) Sorbonne Universités, UPMC Univ Paris 06, UMR 7193, ISTeP, F-75005, Paris, France

(2) CNRS, UMR 7193, ISTeP, F-75005, Paris, France

(3) Beicip-Franlab, 232 Avenue Napoléon Bonaparte, 92500 Rueil- Malmaison, France

(4) CNRS, UMR 6538, Domaines Océaniques, IUEM, UBO, 29280 Plouzané, France

\title{
Corresponding Author:
}

Christian Gorini (christian.gorini@ upmc.fr)

\begin{abstract}
Through several examples we show that following sea-level fall and marginal erosion during the Messinian salinity crisis (MSC), clastic inputs into the eastern and western Mediterranean Sea are not distributed evenly in space and time but are mainly limited to the lower section of the Messinian salinity crisis depositional megasequence. Significant similarities around the basin allow us to propose a Mediterranean Messinian salinity crisis depositional episode that can be divided into two seismic megasequences: the Messinian lower megasequence (MLM)
\end{abstract}


and the Messinian upper megasequence (MUM). Their distinctive seismic facies correspond to systems tracts deposited during three main stages that represent a complete sea level cycle. (1) A falling stage systems tract including mass transport deposits and forced regressive clinoforms deposited in in the early part of the falling stage, and related to the increasing rate of relative sea level fall. This stage is characterized by a marked shift in the depocenter towards the deep basins. (2) An early lowstand characterized by massive clastic inputs from major Messinian rivers (the Rhone, Nile, and Antalya Gulf rivers) or smaller river systems (offshore south Lebanon). These clastics were deposited in an oversaturated basin, as evidenced by the interfingering chaotic and transparent seismic facies of the Messinian lower megasequence (MLM). (3) A late lowstand, starting with rapid deposition of massive halite, with no detrital inputs into the deep basin. The upper part of the evaporites clearly onlaps the Messinian erosional surface at the margins and is evidence for a transition between a late lowstand stage and an early transgressive stage. These deposits belong to the Messinian upper megasequence (MUM). We interpret the transition between the two megasequences as the peak of the "salinity" crisis, the end of the relative sea level fall, and the maximum dispersal of sands into the deep Mediterranean basins.

\section{Key words:}

Messinian salinity crisis, Deep Mediterranean basins, Seismic stratigraphy, Messinian lower megasequence (MLM), Messinian upper megasequence (MUM), dual low stand.

\section{Introduction}

The Messinian event and its repercussions have been the subject of renewed interest both in academia and industry in recent years. MSC paleoceanography continues to be one of the most fascinating topics in its own right, but the potential existence of petroleum systems in 
the subsalt pre-Messinian successions in both eastern and western Mediterranean provinces has also piqued the interest of industry (Belopolsky et al., 2012; Roveri et al., 2014). The MSC was triggered by a combination of tectonic and climatic mechanisms and its effects on Holocene margins are still being felt in terms of deep karsts (Audra et al., 2004), recent slope instabilities (Savoye and Piper 1991), and Quaternary submarine canyons that occupy old topographies (Tassy et al., 2013 and 2014). At the peak of the MSC, the depocenters shifted to the deepest basins (Chumakov, 1973; Ryan, 1978; Barber, 1981; Clauzon, 1982; Gorini et al., 2005; Lofi et al., 2005). Old seismic profiles in the deep Mediterranean basins suggested the presence of evaporites on the seafloor (Mauffret, 1968; Ryan and Hsu, 1970; Mauffret et al 1973; Montadert et al., 1978), and these were ground-truthed in 1970 by the Deep Sea Drilling Program (DSDP) (Ryan, 1973). Since then, three more drilling expeditions (DSDP Leg 42: Hsü et al., 1978; ODP Leg 107: Kastens, et al., 1987; ODP Leg 161: Zahn et al., 1999) were able to sample only the upper veneer of the Messinian upper unit (Lofi et al., 2011b; Fig. 1). The lower part of the Messinian salinity crisis (MSC) megasequence was only poorly seismically imaged (e.g. Hsü et al., 1973a and 1973b; Ryan, 1976; Hsü et al., 1978a; Ryan and Cita, 1978; Mart and Ben Gai, 1982; Garfunkel and Almagor, 1987; Stampfli and Höcker, 1989; Savoye and Piper, 1991; Escutia and Maldonado, 1992), until extensive hydrocarbon exploration in the offshore Mediterranean basins in the last three decades increased both available high-quality seismic lines and well log data. These advances led to new interpretations and publications (since the year 2000: Guennoc et al., 2000; Lofi et al., 2005; Sage et al., 2005; Bertoni and Cartwright, 2006; Maillard et al., 2006; Netzeband et al., 2006; Schattner et al., 2006; Bertoni and Cartwright, 2007a and 2007b; Lofi and Berné; 2008; Bache et al., 2009; Ghielmi et al., 2010; Urgeles et al., 2011; Garcia et al., 2011; Lofi et al., 2011a and 2011b; Maillard et al., 2011; Obone Zue Obame et al., 2011; Bowman, 2012; Geletti et al., 2014; Gaullier et al., 2014). In the eastern Mediterranean Sea, the Messinian 
evaporites in the Nile cone and the Levant areas have been the subject of a number of studies focused on the depositional context of the evaporites (Mart, 1982; Druckman et al., 1995; Buchbinder and Zilberman, 1997; Manzi et al., 2013) and the post-evaporitic structural deformation (Garfunkel and Almagor, 1987; Abdel Aal et al., 2000; Loncke, 2002; Hübscher and Netzeband, 2007; Cartwright and Jackson, 2008; Hübscher and Dümmong, 2011; Reiche et al., 2014). However, there have been few attempts to make a detailed comparison of the stratigraphic architecture of Messinian deposits in the eastern and western Mediterranean (apart from the Atlas, by Lofi et al., 2011a). This paper presents a general pan-Mediterranean scenario for the Messinian erosional and salinity crisis that could alter our view of the potential presence of hydrocarbon reservoirs. In addition, it could help plan academic IODP drilling locations in both the western and eastern Mediterranean.

\section{Brief review of knowledge of the different sub-basins}

The sequestration of the Mediterranean Sea from the adjacent oceans at the end of the Miocene caused significant evaporation of seawater and increased the evaporitic concentration of the Mediterranean Sea (Blanc, 2000, 2006; Meijer and Krijgsman, 2005; Meijer, 2006; Gargani and Rigollet, 2007; Gargani et al., 2008). As a result, a thick (up to 2 $\mathrm{km}$ ) sequence of evaporites was deposited in the center of its deep basins (Hsü et al., 1973; Cita, 1973; Ryan, 1973; Garfunkel and Almagor, 1987). This deposition coincided with intense subaerial erosion of the basin margins (Denizot, 1952; Barr and Walker, 1973; Chumakov, 1973; Clauzon, 1973, 1978, 1982; Gvirtzman and Buchbinder, 1978; Hsü et al., 1978a; Ryan and Cita, 1978; Barber, 1981; Savoye and Piper, 1991; Druckman et al., 1995; Guennoc et al., 2000; Lofi et al., 2005; Ryan, 2009; Bache et al., 2009). The Messinian salinity crisis ended with catastrophic re-flooding (Garcia-Castellanos et al., 2009; Estrada et al., 2011). However, it took a few million years for sedimentation in the Mediterranean to 
rebuild its slopes and shelves to the modern and pre-MSC configurations (Lofi et al., 2003; Urgeles et al., 2011; Leroux et al., 2014). Contemporaneously, Messinian valleys and canyons identified on seismic lines and in drill cores, were infilled and buried (Druckman et al., 1995; Buchbinder and Zilberman, 1997; Guennoc et al., 2000). The amplitude of the sea level rise that led to the reestablishment of marine conditions in the Mediterranean is attested by the geometries of the deltaic progradational-aggradational wedges above the MES (Lofi et al., 2003; Duvail et al., 2005; Gorini et al., 2005, Kertznus and Kneller, 2009; Hawie et al., 2013b, Leroux et al., 2014). In addition, clinoform geometries are good paleodepth indicators (Urgeles et al., 2011; Rabineau et al., 2014) that provide an estimated sea level rise of 800$1000 \mathrm{~m}$ (above the last Messinian lowstand paleoshore position, Leroux et al., 2014). Since the Oligocene, the Levant margin and basin sediments have been sourced mostly from the Nile (Hawie et al., 2013b; Tibor et al, 1992; Druckman et al., 1995, Fig. 1). Sediments in the western Mediterranean basin mainly originated from the Rhone and Ebro since the Tortonian (Gorini et al., 2005; Lofi et al., 2005; Bache et al., 2009; Garcia et al., 2011; Urgeles et al., 2011; Estrada et al., 2011; Fig. 1). The paroxysm of the MSC started around 5.6 Ma (CIESM Consensus Report, 2008). The debate concerning the amplitude of sea-level drop associated with this crisis continues (see for example: Lugli et al., 2013; Roveri et al., 2014). Also, the amount of erosion and clastic input in the deep basin is not wholly agreed upon (see e.g., Lofi and Berné, 2008 vs. Bache et al., 2012).

\section{Imaging the Eastern Mediterranean Messinian Deep Basin}

\subsection{The NW Levant Basin: A stratigraphic type section}

Understanding the seismic stratigraphy of the Messinian evaporites is challenging in that it is often hindered by the ductile state of the mobile unit (MU) and its subsequent internal deformation [(e.g., in the Herodotus Basin (Loncke et al., 2006) or next to the Levantine 
eastern margin (Netzeband et al., 2006; Hübscher and Dümmong 2011; Reiche et al., 2014)]. Nevertheless, most of the Levant basin remains rather undeformed. Therefore, investigating the Levant basin is crucial to unravelling the stratigraphic evolution of the Messinian evaporites.

Figure 2 shows the seismic stratigraphic subdivisions used along a seismic profile located in the NW Levant basin (Fig.2a). Five major units can be identified within the 1,500 m thick layer of Messinian evaporites (Fig. 2b).

- Unit A is limited to the base and top by high-amplitude reflectors. The configuration of the internal seismic facies is similar to the underlying Miocene units, with presumably high detrital content. The base of the Messinian salinity crisis (MSC) depositional sequence can be identified exactly at the base of Unit A (see Figs. $2 b$ and $3 b$, and the discussion section).

- $\underline{\text { Unit B }}$ is transparent, with intercalations of high frequency reflectors. Deformation is visible within this unit, indicating the presence of mobile/ductile materials (i.e. halite, Hübscher and Dümmong, 2011).

- Unit $\mathrm{C}$ is composed of a set of high amplitude reflectors separated by more transparent intervals that may represent halite. The nature of the high amplitude reflectors is uncertain (e.g. acoustic impedance contrast between evaporites of different nature or detritic levels). Results of the inversion of seismic data collected in the northern Levantine basin suggest the presence of clastics (Fig. 2c, Montadert et al., 2014).

- Unit D is similar to Unit B with transparent seismic facies indicating another mobile unit (halite deposits) with some intercalated high frequency reflectors that are more frequent towards the top of the unit.

-Unit $\mathrm{E}$ is characterized by high frequency reflectors, pointing to high frequency hydrological changes at the top of the MSC Megasequence. This unit corresponds to the uppermost stratified Messinian unit ME V previously described by other authors (Hübscher and 
Dümmong 2011; Dümmong and Hübscher, 2011; Gvirtzman et al., 2013; Reiche et al., 2014). It shows reduced refraction velocities $(3,700-3,600 \mathrm{~m} / \mathrm{s})$, suggesting intercalated gypsum and clastics. A high amplitude reflector marks the top of unit E (Top erosion surface: Hübscher and Dümmong 2011; Reiche et al., 2014) and the boundary with the Pliocene sediments characterized by low seismic velocities (2,600m/s; Gvirtzman et al., 2013).

Other authors agree with a basic subdivision of the succession into five main units [(Netzeband et al., 2006) see also: (Cartwright et al., 2012) on the Israeli margin with their M1-M5 units], although six units have been described in the westernmost part of the basin [Bertoni and Cartwright, 2007 (T1-T4 and L1-L2); Hübscher et al., 2008; Cartwright and Jackson, 2008; Maillard et al., 2011; Dümmong and Hübscher, 2011; Gvirtzman et al., 2013]. These areas show thin-skinned salt tectonic activity.

In the northern part of the Levant margin, the onshore drainage basin is characterized by carbonate dominated rocks and restricted river systems (Hawie et al., 2013a, 2013b), which limit siliciclastic inputs. Offshore the Lebanon margin, the Messinian clastics are limited to the lower slope and the lower half of the evaporite interval (Fig. 3b).

\subsection{Correlation with the Nile margin: Thick clastic unit at the base of the Messinian event}

In the Nile deep sea fan in the Herodotus Basin, considerable amounts of sediments have been deposited along the Egyptian margin since the Oligocene (Fig. 1). The Messinian sea level drop increased the role of the Nile as a conduit for sediments. Subaerial erosion affected large areas of the former Miocene Nile cone (Montadert et al., 2014). Seismic profiles suggest that during this period as well as during the Pliocene-Pleistocene, most of the sediments were diverted westward by the prominent Eratosthenes continental block (Montadert et al., 2014; Fig.1). The seismic lines (Fig. $4 \mathrm{~b}$ and $4 \mathrm{c}$ ) in the lower part of the Nile cone display intercalation of a large, thick clastic unit (about 2,000 $\mathrm{m}$ thick) at the base of the MSC 
megasequence. This unit corresponds to the Messinian lowstand Nile delta-fed clastics (gravity flow deposits). In detail, stacked channel complex systems characterize this seismic facies (Montadert et al., 2014).

The change in the lateral facies between this clastic deposits (low frequency, high amplitude, low continuity reflections) and halite (transparent seismic facies), which is clearly visible in Figs. $3 b, 4 b$ and $4 c$, is evidence that these clastics accumulated in a restricted hypersaline Messinian basin. Messinian clastics were eroded from the shelf margins and redeposited in the deep basins during the early stages of the Upper Messinian sea level drop. They interfinger with evaporite deposits and therefore fully belong to the MSC event. Caution is therefore called for in defining the base of the MSC event on seismic profiles in the deep Mediterranean basin, e.g., choosing the base of the transparent layer (halite) as the base of the Messinian salinity crisis deposits, particularly in front of the big rivers, would lead to false/incomplete interpretations. Hence the base of the MSC event must be located at the base of these high frequency reflections.

\subsection{Correlation with the Florence Ridge: the Antalya Basin}

The Antalya Basin is located north of the Florence Ridge (Biju-Duval et al., 1978, 1979; Fig. 5a) and is part of the Cyprus arc system. This basin was formed after the emplacement of the Cyprus arc during the Late Cretaceous and later infilled by a thick Cenozoic cover with sediments sourced from Turkey (Fig. 1 and Fig. 5a). Thick Messinian evaporites are observed in this basin similar to those seen in the nearby Herodotus Basin (Fig 5b). The Antalya and Herodotus basins used to be connected, whereas isolated Messinian islands persisted along the Florence Ridge (Biju-Duval et al., 1978, 1979).

In the seismic profiles (Fig. 5b), the same stratigraphic stacking pattern can be seen as in the Levant Basin (Fig. 2b and Fig. 3b). Continuous reflectors (Unit C) can be observed in 
between more transparent facies (Units B and D, we interpret as halite). Fig. 5b depicts a large clastic body that laterally corresponds to Units A, B and C. It is consequently located within the lower half of the MSC depositional megasequence. The top of sequence $\mathrm{C}$ marks the transition from the lower part of the MSC megasequence, where clastic inputs dominate, to the upper part of the MSC megasequence, where evaporites dominate.

\section{Geometries and facies distribution in the western and eastern Mediterranean: a comparison}

The MSC seismic stratigraphy off the Rhone River was defined by Ryan et al. (1973), Bessis (1986), Bache et al. (2009), Ryan (2009), Lofi et al. (2011a, 2011b). Differences in facies and geometries between the western and eastern Mediterranean were identified by these authors. The MSC megasequence is commonly subdivided into three units: the lower unit (LU), the mobile unit (MU) and the upper unit (UU)- However, we propose to subdivide the thick megasequence into two layers in both basins that are comparable in terms of thickness and seismic signature (Fig.6a and Fig.6b): the Messinian lower megasequence (MLM) and the Messinian upper megasequence (MUM). An improved correlation between the two deep basins is provided here.

\subsection{The MSC Lower Megasequence (MLM)}

In the eastern Mediterranean the $\mathrm{A}, \mathrm{B}$ and $\mathrm{C}$ subunits are grouped in the Messinian lower megasequence (MLM). In front of the biggest Messinian rivers, like in the distal part of the Nile Messinian cone, or off the Rhone deep sea fan, the MLM unit is imaged by a chaotic seismic facies we interpret as stacked systems of mixed silicoclastic sediments and evaporites. In the eastern basin, units $\mathrm{A} B$ and $\mathrm{C}$ are stacked in one seismic facies in front of the Nile, Levantine and Antalyan rivers (Figs.3b, 4b, 4c and 5b). The seismic facies and the thickness 
of this lower unit resemble those of the lower unit (LU) described by Bache et al. (2009) and Ryan (2009) in the western basin (labelled 2 in Fig. 6a). Note that the LU described by Bache et al., (2009) is much thicker than the LU described by Lofi et al., (2011a). In the western basin, this unit is up to $2.5 \mathrm{~km}$ thick using ESP velocity (Leroux, 2012). We interpret the complex features and internal erosions in both the Rhone deep sea fan and in the Nile cone as channels (labelled 2 in Fig. 6a and Fig. 6b). On top of this MLM, chaotic facies are also visible (labelled 5 in Fig. 6a) and that we suggest are the result of instabilities triggered by the rapid sea level drop (Gargani et al., 2014),which was still underway at the peak of the Messinian crisis. As stated in section 3, the change in the lateral facies from high-amplitude seismic facies to the transparent seismic facies in the eastern basin (Figs. 3 to 6) shows that the clastics were redeposited in a hypersaline environment. High P wave velocities in the Messinian lower megasequence, point to the probable alternation of evaporate sedimentation and clastics in both the western Mediterranean (Leroux, 2012) and eastern Mediterranean (Montadert et al., 2014). The explanation for these alternations is that in front of the big rivers, saline concentrations were diluted by fluxes of riverine water leading to the deposition and intercalation of shale, gypsum and halite. In this interpretation, clastic deposits are synchronous with the deposition of evaporites in the deep basins.

Upslope, high angle clinoforms have been described (Bache et al., 2009; Leroux, 2012, labelled 1 in fig. 6) with an underlying surface of marine erosion (regressive surface of marine erosion, RSME). We interpret these clinoforms as forced regressive deltas related to the increasing rate of MSC sea level fall. Similar (but smaller) forced regressive systems have been described on the outer shelf and were deposited during the glacio-eustatic falling stages in the Late Quaternary (Berné et al., 2004; Rabineau et al., 2005, 2006) and were later ground-truthed by drilling (Bassetti et al., 2008). These forced regressive deltas are related to 100,000 year glacio-eustatic cycles with an overall sea level fall of $120 \mathrm{~m}$. The observed 
Messinian prisms are located much deeper and more seaward on the slope, with steeper clinoforms, indicating a much larger drop in sea level (Bache et al., 2009; Urgeles et al., 2011), i.e. between $800 \mathrm{~m}$ and $1,500 \mathrm{~m}$.

\subsection{The Messinian Upper Megasequence (MUM)}

We divide the MUM into two corresponding to unit D and $\mathrm{E}$ in the eastern Basin (Figs.3b, $4 \mathrm{~b}$, 4c and 5b) and to the mobile unit (MU, labelled 6 in Fig.6a) and upper unit (UU, labelled 7 in Fig. 6a) of (Lofi et al., 2011a, 2011b) in the western basin. In the western and eastern area, the MUM is comparable in terms of thickness (0.5 TWT) and seismic facies (high amplitude reflections on top of a thick transparent unit). In detail, the top of the MUM shows lateral variations, e.g., transparent facies between high amplitude reflections (Reiche et al., 2014; Geletti et al., 2014; Fig. 5b). In the western basin, the upper part of the MUM clearly onlaps the Messinian canyons and the incised valleys (Fig. 7). This architecture has already been described in proximal settings throughout the western Mediterranean (Montadert et al, 1978; Sage et al., 2005, Lofi et al., 2011a, 2011b; Figs. 7a, 7b, 7c) and the eastern Mediterranean (Gargani and Rigollet, 2007).

The top of the MSC megasequence has been strongly eroded in most parts of the eastern and western deep basins. For example, on the Florence Ridge west of the island of Cyprus, the thick Messinian evaporites are clearly eroded, resulting in a flat surface (Fig. 8). The same substantial erosion of the top of the MSC megasequence is also visible in the western basin (labelled top erosional surface, TES on Fig. 6, a").

\subsection{Partial ground-truthing}

A review of drilling sites and samples in the Mediterranean shows that: 
1- In medium water depths ( 1,500 m; Sites 371, 372, 375376 and GLP2, Fig.1) the intercalation of sands, marls, gypsum and halite characterize the upper part of MUM (labelled 7 in Figs. 6a and 6b). These evaporites onlap the Messinian maximum regressive erosional surfaces (MES in Fig. 7c). In the most proximal part of the margins, this sequence corresponds to aggrading fluvial conglomeratic deposits (Fig.7c) during the late MSC lowstand related to a drainage network with tributaries, terraces and meandering rivers, i.e. the incised valley fill described by Savoye and Pipper (1991) and Urgeles et al., (2011).

2- The Mediterranean reflooding was much more erosive than often described, even at great depth. In most drill cores, the upper part of the MUM revealed reworked evaporitic deposits and sands deposited during the uppermost Messinian (5.46-5.33 Ma, Bache et al., 2012). These observations are consistent with an early slower apparent transgression inducing wave ravinement reworking (with sands and evaporites) followed by the rapid and erosive reflooding event (Garcia-Castellanos et al., 2009; Estrada et al., 2011).

\section{Proposed conceptual model}

Based on our observations and on our interpretation of the new seismic lines, we assume that the complete sedimentary record of the MSC is preserved only below the present-day Mediterranean seafloor of the deep central basins. The deep central Messinian basins (Fig. 1) match the present-day Mediterranean slopes and bathyal plains around the Ligurian-Provencal Basin (30 My old basement) and the eastern basin (Tethysian basement). Peripheral and intermediate basins accessible in the field and described in the literature refer to their position with respect to these deep basins. A set of terms was taken from the sequential stratigraphy (Catuneanu et al., 2011) to facilitate the description and the proposed interpretation, but the Messinian depositional megasequence requires the definition of a model-independent methodology for the deep Messinian Mediterranean basin, which was disconnected from the 
global ocean during the MSC and characterized by a giant salt deposit. We have divided the MSC depositional megasequence associated with a complete relative sea level (RSL) cycle into two MSC sub-units of the same RSL cycle in both the eastern and western deep basins, and we have refined the earlier observations (Lofi et al., 2011a).

The Messinian Lower Megasequence (MLM)

The onset of the MSC relative sea level fall is marked by a regressive surface of marine erosion (RSME, Fig. 10). Mass transport complexes (MTCs) and forced regressive prisms (labelled 1 on fig 10) are visible at the transition between the slope and the deep Messinian basin. Clastics were deposited at the mouth of the first Messinian incised valleys. The RSME is an erosional truncation we interpret as scars of mega slides triggered by the high rate of the sea level fall at that time. The thick chaotic seismic facies at the transition between the Miocene slope and the deep basin (labelled 1 in Fig. 6) is evidence for the occurrence of instabilities during the uncommonly high rate and amplitude of sea level variation during the MSC megacycle. In the deep basin, the continuation of this surface is a correlative conformity (MES-CC*, Fig. 10) in the sense of Posamentier and Allen (1999) and defines the base of the MLM in the deep basin. In the distal part of the big deltas, the MLM is characterized by seismic facies we interpret as deep-water clastics deposited in a hypersaline environment. The major drop in sea level occurred when the connections were restricted, at 5.6 Ma according to a now widely accepted time model, CIESM (2008). Observations from paleoshelves indicate high rates of erosion of at least $1 \mathrm{~km}$ during the event (Lofi et al., 2005; Rubino et al 2005, Bache, 2008; Bache et al., 2009); more recently quantified at $1.3 \mathrm{~km}$ (Rabineau et al., 2014). The high rate of the sea level fall, coupled with a high sediment flux in front of major rivers, led to a strongly decreasing accommodation/sediment supply ratio. This paper shows that in the deep eastern Mediterranean basin, the falling stage is clearly associated with the beginning of evaporite/halite precipitation, the subsidence at that time allowed the accumulation of more 
than 2,000 $\mathrm{m}$ of mixed silicoclastic/evaporitic sediments (early low stand). We envisage deposition occurring below relatively deep-water conditions (600-1,000 m below wave base) with a coeval Mediterranean-wide halite deposition. In this scenario, halite accumulated in a subaqueous environment during the sea level drop and its deposition was ended by a quasiinstantaneous salt precipitation on top of the Lower Messinian megasequence. We hypothesize that the strong net evaporation, which concentrated Mediterranean seawater prior to drawdown, resulted in this rapid precipitation of halite at the lowest sea level. The strong acoustic impedance contrasts within eastern halite deposits (Units A, B and C) were interpreted as clastic intercalations (Bertoni and Cartwright 2007b, Figs. $2 b$ and 2c). Tributaries located around the margins were the source of clastic and meteoric waters (Figs. 4 and 5). These facies were previously interpreted as turbidite deposits due to their distribution at the mouth of Israeli canyons (Lugli et al., 2013) and Lebanon canyons (Hawie et al., 2013b). On the Levant margin, canyon incisions were superimposed on preexisting canyons (Druckman et al., 1995; Gardosh et al., 2008; Hawie et al., 2013b). Israeli canyons are filled by MTD deposited interpreted by others as subaqueous gravity flows (reworked evaporites and clastic sampled in Mavqi'im and Be'eri evaporites, Lugli et al., 2013). We hypothesize that these "gravity flows" (mass transport deposits) originated during the initial falling stage and are coeval with the MLM depositional sequence. This is not incompatible with the formation of subaerial incisions upslope (valleys) and the later development of a widespread erosion surface characterizing the Mediterranean fluvial network on platforms at the continental margins (Rubino et al., 2010). Large-scale mass wasting processes along the shelf margins and slopes following or coeval with the Messinian drawdown are reported all around the Mediterranean (Gargani et al., 2014, Bowman, 2012).

A combination of several sea level drawdown events in the Mediterranean, associated with limited seawater inflow and continuous river discharge, is needed to explain the quantity of 
evaporites deposited in a very short time and could explain the alternation between clastics and evaporites suggested by the indentation between Messinian Nile lowstand and salt (Figs. $4 \mathrm{~b}$ and $4 \mathrm{c})$.

In the saline eastern basin, the top of the MLM corresponds to unit C. This group of reflectors at the top of the MLM constitutes a sharp regional contrast between the MLM and the MUM (Figs. $2 \mathrm{~b}$ and $2 \mathrm{c}, 3$ to 6). Based on seismic velocities, other authors have interpreted this stratified unit as embedded clastics, or a more diluted facies, such as limestone, anhydrite, or high salinity deliquescent facies (Sylvinite, Carnallite; Vp 3-3.9 Km/s eg. Bertoni and Cartwright, 2006; Hübscher et al., 2008; Lofi et al., 2011a). Several hypotheses can be proposed to explain the nature of the transition between the MLM and the MUM throughout the Mediterranean (Figs. 2, 3 and 5). A layered seismic facies is widely observed in evaporitic systems and has generally been linked to changes in lithology, i.e. to the alternation of bitterns, dolomite, anhydrite, halite and/or siliciclastic sediments (e.g. Upper Permian basin in the North Sea: Birrel and Courtier, 1999; Aptian evaporites of the Santos basin: Gamboa, 2004). A definitive interpretation of the seismic facies is not possible at this stage, and will require direct well calibration. Nevertheless, we propose a theory to explain the nature of the transition between the two seismic megasequences. The sharp reflectors at the top of the MLM are either detrital or diluted sediments. In either case they correspond to the increase in the influx from the rivers around the Mediterranean in a period when the connections between the deep basins and the world oceans were at least seriously limited. When the sea level was at its lowest, the salinity concentration and the flux of clastics and meteoric water in the deep basins were at their highest. Moreover, the influx from North African rivers to the basin may have been higher at that stage due to a major change in monsoon intensity after 6.2 My (Colin et al., 2014). 
Our observations (Figs. 2, 3, 4, 5, 6) suggest that the top of the MLM corresponds to the maximum spread of clastics and meteoric water in the deep MSC basins. This "turning point" is equivalent to the correlative conformity in the sense of Hunt and Tucker (1992), which we interpret as the peak of the "salinity" crisis. The clastics fans in the deep basin ( 2 in Fig. 10) and the evaporites (3 in Fig. 10) are comparable to the early low stand systems tract described in the Exxon models (Catuneanu et al., 2011). The MLM depositional sequence generated during the MSC falling stage thus corresponds to an early low stand deposited during a high rate of MSC relative sea level fall. MLM clastic fans and evaporates are the equivalent of a falling stage systems tract (FSST in Fig. 11, Catuneanu et al., 2011) at the scale of the MSC depositional megasequence (more than 2,000 m of sediments).

The Messinian Upper Megasequence:

Significant changes in the paleogeography of the Mediterranean Sea at the end of the MSC led to the reorganization of the atmospheric circulation and drier conditions over North Africa (Colin et al., 2014). At that point, salt started to precipitate, probably very rapidly (lower part of the MUM).

The MUM has already been described by other authors (Lofi et al., 2005; Bache et al., 2009; Lofi et al., 2012) and has been partially drilled at its top (Fig. 9). It consists of a transparent unit (halite, e.g. a mobile unit, Lofi et al., 2011a) and a more diluted facies at the top (Unit E, alternations between gypsum and fine marine clastics, upper unit described by Lofi et al., 2011a)

The characteristic transparent seismic signature of the MUM is due to the prevailing conditions when the river flux into the basin was minimal. This points to a major change in the depositional environment, e.g. (1) detrital material that was trapped upslope due to a rapid increase in accommodation coeval with the rapid precipitation of salt (relatively reflectionfree seismic facies resulting from a very high rate of halite precipitation) infilling canyons in 
their deeper parts; (2) a change in the climate to more arid conditions; (3) rivers reached their base level. Even if the onset of the MSC was initially affected by the tectonically-driven reduction in the hydrological exchange with the Atlantic Ocean, some authors point out that it was finally triggered by glacial conditions in the northern Hemisphere and by arid conditions in North Africa around 5.55 Ma (Manzi et al., 2013; Roveri et al., 2014). At that stage, the MUM (and its deposits labelled 5 and 6 and 7 in Fig.10) started to be precipitated/deposited on a flat Messinian "erosional or bypass surface" on top the intermediate basins seafloor (of which the bottom was located near the Messinian base level) e.g. the Valence basin (Maillard et al., 2006; Garcia et al., 2011), the Algerian basin (see Fig. 3 in Lofi et al., 2011a, and Fig. 10), and the Sicilian basin (Bowan, 2012; Roveri et al., 2008, 2014).

Whatever the reason for this change in the depositional environment, salt/evaporites continued to precipitate in the deep basins until the sea started to transgress widely. This is illustrated by the seismic facies and geometries at the top of the MUM (Figs. 7 and 9). At that stage, evaporites (gypsum and salt (Geletti et al., 2014, Fig. 9)) altering with marls/shales (Fig. 9) started to be deposited in the "deep basin" passing upslope to late lowstand aggrading fluvial conglomerates infilling the Messinian valleys (Fig. 7c, Maillard et al., 2006; Urgeles et al., 2011; Sage et al., 2005; Obone Zue Obame et al., 2011; Sage and Déverchère, 2011). The MES-CC** (correlative conformity of the MES, in the sense of Hunt and Tucker (1992) in Catuneanu et al., 2011, Fig. 10) is the base of the MUM. The mobile unit (labelled 5 in Fig. 10), the upper unit (labelled 6 in Fig. 10) and the fluvial incised valleys fill (7a on Fig. 10) onlapping the MES surface were coeval with an MSC RSL rise (low rate). During this event, the deep basin was still restricted and the accommodation space was rapidly filled by the evaporites. Thus the evaporites and fine clastics (shales) of the MUM correspond to the MSC late lowstand systems tract (LST in Fig. 10). At the top of the Messinian upper megasequence (MUM) transgressive marine sands (7b) and material reworked by the giant reflooding (8) 
were deposited during an early transgression. The marine ravinement surface eroded and flattened the irregular morphology of the MES (Garcia et al., 2011; Bache et al., 2011). In the eastern basin, the Messinian upper megasequence was associated with sequences D and E of the type section of the NW Levant Basin (M-IV, ME-5, ME-VI of Dümmong and Hübsher, 2011). This late lowstand onlapping (aggrading) on the margin progressively hindered the arrival of clastic material in the basin (apparent transgression). The late stage of this lowstand was characterized by an increase in base level with onlap onto the MES of evaporites/or clastic materials [Fig 7; Lofi et al., 2011a (Fig. 7), Luigli et al., 2013 (Fig. 7); Geletti et al., 2014 (Fig.12)]. The dilution and shift towards an evaporite series mainly composed of marls, anhydrite and salt occurred in the later stages in both the western and eastern basins, although it is more obvious in the western basin. During the deposition of fluvio-deltaic clastics of the uppermost Messinian upslope in the incised valleys (Fig 7c, labelled 7a on Fig. 10), a minimum water level most likely persisted downslope in the deep basins, meaning that complete desiccation did not take place (Hardie, and Lowenstein, 2004). During the MUM deposition in the deep basin, Messinian continental facies were full lacustrine when perched lakes were disconnected from the deep basin. The variability in depositional environments during the MSC depositional megasequence explains the variety of Messinian seismic facies [e.g. the bedded unit (BU)], Maillard et al., 2006; Guennoc et al., 2011; Thinon et al., 2011). At the peak of the MSC, the currently visible erosion of the upper part of these facies interpreted as lago-mare facies (Bowman, 2012), could have been caused by the rapid draining of the perched lakes (Thinon et al., 2011). A recent model establishes an interesting scenario that attempts to correlate these intermediate settings with a deep setting (Roveri et al., 2014). However these authors based their models on incomplete seismic records of the MSC (Lofi et al., 2011a and b). 
As our first conclusion, we propose that the Messinian sedimentary evolution of both western and eastern basins was similar. Therefore, we propose a regional model that unites the western and eastern Mediterranean (Fig. 10). This model is based on observations and previous works throughout the Mediterranean and the margins outlined above: Strong net evaporation concentrated Mediterranean seawater was coeval with drawdown and resulted in the rapid precipitation of halite during the sea level fall, with an optimum marking the transition between the top of the Messinian lower megasequence (MLM) and the Messinian upper megasequence (MUM). We assume that the rapid infilling of the Messinian accommodation by clastics and evaporites in the deep basin resulted from a marked reduction in the seaway connections at the Gibraltar arc region at 5.6 Ma. This ended with the reconnection/reopening of the world's oceans via the Gibraltar Straights at around 5.46 Ma. However, without a proven age model, it is risky to give ages to this sequential interpretation. The variability of facies throughout the Mediterranean basin, including the variations in the thickness of the mobile unit, can be explained by:

1) the paleogeographic position of the basins and their margins during the MSC;

2) by the presence or absence of large clastic and meteoric water pathways flowing into the saline basins.

From 5.97 to 5.6 evaporites precipitated in shallow sub-basins (Manzi et al, 2013); the MSC peaked when evaporite precipitation shifted at 5.6 to the deepest depocenters and the peripheral basin started to be eroded (purple area in Fig. 10; Topped by the MES);

The two major seismic megasequences in the two Mediterranean deep basins correspond to five major stages: (1) an initial stage of progressive increase in salinity; (2) a falling stage with detrital and evaporite deposition; (3) a late lowstand with rapid precipitation of salt, (4) the final stages of the MSC with a decrease in salinity due to the beginning of dilution, (5) an 
early transgressive stage with the deposition of marine sands. This Messinian depositional megasequence ended with a reflooding coeval with a worldwide rise in sea level (5.46-5.33)

The Messinian lower megasequence (MLM) corresponds to a rapid relative sea level fall in a hyper saline deep basin. The water column still represented by 500-1,000 $\mathrm{m}$ of dense water. The systems tract associated with this seismic megasequence is characterized by: (1) forced regressive deltas and instabilities (upslope scours and MTD in the basin and canyon flanks), (2) widening of canyons and the deposition of turbidites in front of the big deltas. River profiles tended to readjust with time leading to the continuous generation of Messinian subaerial erosional surfaces (MES in Fig. 10) on top of peripheral basins (PB in Fig. 10). Clastic sedimentation was not distributed evenly over time but was localized in the MLM (eastern basin and northwestern basin) and the deposition of deep sea fans located in front of major deltas/canyons in the deep basins (2 in Fig. 10) was synchronous with the first evaporite deposition in the eastern basin (seismic facies) and probably synchronous with the evaporite deposition in the western basin (based on seismic velocities and detailed seismic facies). All the Messinian depressions shallower than 1,500 m became subaerially exposed after the maximum drop in the base level, and underwent erosion and/or eventual bypass. The basinward extension of the MES, i.e. its correlative continuity, in front of the big Messinian river canyons will likely be traced to a much lower position than previously defined. The deposition of MLM massive evaporites and detritals resulted in significant loads and predicts differential acceleration of basement subsidence between the young western basins (Oligocene-Aquitanian) and the eastern deep basin located on Tethysian remnants. The differential subsidence between deep basins and their platform as well as the sea level drop, caused major instabilities. The sharp transition between MLM and MUM is coeval with the lowest sea level that occurred in the Messinian megacycle. The MUM corresponds to an apparent base level rise with onlaps on the MSC erosional surfaces. This can be linked to a 
constant marine water flux leading to the deposition of thick halite in both basins and reducing influxes from rivers. The MUM constitutes an upper succession of shallow to moderately deep-water deposits $(5,6,7,8 \mathrm{~b}, 8 \mathrm{a}$ on Fig. 10). Geometrical features and seismic facies in the dataset are evidence for an increasing accommodation/sediment supply ratio during the deposition of these "upper evaporites". This aggradation was commonly coupled with maximum regression. From these observations, we interpret this complex MUM megasequence as a late lowstand. This stage could have begun with a period characterized by large-scale environmental fluctuations in a Mediterranean transformed in some places to brackish water (suspended lakes in an intermediate position between the peripherals basins and the deep basins) and the rapid precipitation of massive halite in the deep settings, controlled by a drier climate. MUM could correspond to the uppermost units of Sicily and Cyprus (5.5 Ma to $5.46 \mathrm{Ma}$ ) described previously. This scenario ends with catastrophic flooding due to the collapse of the Straights of Gibraltar. Polyphasic Messinian erosional surfaces (MES, RS and TES) are fossilized by the Zanclean hemi-pelagic marls (labelled 9a in Fig. 10). Reworked evaporites and deep water sands are widely observed in ODP drilling lithology (labelled 8 in Fig. 10) attesting to the permanency of high energy and erosive sea bottom currents during the Zanclean. In the Alboran Basin, the huge seawater flow significantly eroded the Messinian subcropping units (Estrada et al., 2011). The missing material could correspond to thick "chaotic / channelized" units on top of the upper megasequence of the Algero-Baleares basin.

\section{Conclusion}

We propose that during the salinity crisis, the Messinian evolution of both the eastern and western deep basins is recorded in two seismic megasequences corresponding to a dual lowstand depositional model: The Messinian lower megasequence (MLM) corresponds to the 
shift of Messinian clastics depocenters to the deeper parts of the hypersaline waters of the basins. The top of the MLM is coeval with the lowest MSC sea level and with the sharp transition to the Messinian upper megasequence (MUM). The MUM records the rapid precipitation of massive halite that filled the accommodation space. We interpret the MUM as a late lowstand related to a decreasing rate in the RSL fall accompanied by a progressive increase in the accommodation (relative sea level) and sea water supply. Our seismic interpretation of the Messinian series on the Mediterranean shows that it is important (but challenging) to distinguish between geometries due to three processes: (1) erosional truncations that occurred during the Messinian falling stage; and (2) marine ravinement surfaces caused by an early transgression at the end of the MSC; (3) severe erosion at the top of the Messinian Alboran Sea floor and the basinal evaporites caused by the strong currents during the reflooding period. The previous partial record of the MSC was due to the peripheral/intermediate position of the basins. In the deep offshore, deposits related to the MSC are a major component of the petroleum system with thick extensive sandstones or mass transport complexes with evaporites, sealed by Messinian evaporites and sourced by Messinian or older source rocks.

\section{Acknowledgements}

We thank Petroceltic International PLC, Petroleum Geoservices PGS and Spectrum which approved our use of the seismic line, TGS as the original acquirers and processors of the processed migration of the seismic line in fig.6a, Françoise Sage, Sebastien Migeon and Jean Xavier Dessa and the INSU CNRS for the acquisition and processing of the seismic line in Fig.7c (UPMC marine geology training). Two reviewers, F. Roure and M. Rossi, and the editor J.P. Suc are greatly acknowledged for their examination of our manuscript and their comments and recommendations which helped us to significantly improve it. We also thank 
Daphne Goodfellow for her language corrections and comments on the manuscript, Alexandre Lethier who helped us for the figures, and Jean-Loup Rubino for the fruitful discussions. This work is a contribution to the French program Action Marge and INSU Mistral-Termex program. The processed seismic data were interpreted thanks to the Kingdom Suite $\odot$ software.

\section{References}

Aal, A., El Barkooky, A., Gerrits, M., Meyer, H., Schwander, M., Zaki, H., 2000. Tectonic evolution of the Eastern Mediterranean Basin and its significance for hydrocarbon prospectivity in the ultradeepwater of the Nile delta. The Leading Edge 19, 1086-1102.

Audra, P., Mocochain, L., Camus, H., Gilli, E., Clauzon, G., Bigot, J.-Y., 2004. The effect of the Messinian Deep Stage on karst development around the French Mediterranean. Geodin. Acta 17, 389-400.

Bache, F., 2008. Evolution Oligo-Mioce`ne des Marges du Micro Océan Liguro-Provençal (PhD Thesis). Université de Bretagne Occidentale, Brest, p. 328.

Bache, F., Gargani, J., Suc, J.-P., Gorini, C., Rabineau, M., Popescu, S.-M., Leroux, E., Do Couto, D., Jouannic, G., Rubino, J.-L., Olivet, J.-L., Clauzon, G., Dos Reis, A.T., Aslanian, D., submitted. Messinian evaporite deposition during sea level rise in the Gulf of Lions (Western Mediterranean). Mar. Petrol. Geol. this issue.

Bache, F., Olivet, J.-L., Gorini, C., Rabineau, M., Baztan, J., Aslanian, D., Suc, J.-P., 2009. Messinian erosional and salinity crisis: view from the Provence basin (Gulf of Lions, western Mediterranean). Earth Planet. Sci. Lett 286, 139-157.

Bache, F., Popescu, S.-M., Rabineau, M., Gorini, C., Suc, J.-P., Clauzon, G., Olivet, J.-L., Rubino, J.-L., Melinte-Dobrinescu, M.C., Estrada, F., Londeix, L., Armijo, R., Meyer, B., 
Jolivet, L., Jouannic, G., Leroux, E., Aslanian, D., Dos Reis, A.T., Mocochain, L., Dumurdžanov, N., Zagorchev, I., Lesić, V., Tomić, D., Çağatay, M.N., Brun, J.-P., Sokoutis, D., Csato, I., Ucarkus, G., Çakir, Z., 2012. A two-step process for the reflooding of the Mediterranean after the Messinian Salinity Crisis. Basin Res. 24, 125153.

Barber, P.M., 1981. Messinian subaerial erosion of the proto-Nile delta. Mar. Geol. 44, $253-$ 272.

Barr, F.T., Walker, B.R., 1973. Late Tertiary channel system in Northern Libya and its implications on Mediterranean sea level changes. In: Ryan, W.B.F., Hsü, K.J., et al. (Eds.), Leg 13, Initial Reports of Deep Sea Drilling Project, vol. 13, pp. 1244-1255.

Bassetti, M. A., Berné, S., Jouet, G., Taviani, M., Dennielou, B., Flores, J.-A., Gaillot, A., Gelfort, R., Lafuerza, S., Sultan, N., 2008. The 100-ka and rapid sea level changes recorded by prograding shelf sand bodies in the Gulf of Lions (western Mediterranean Sea), Geochem. Geophys. Geosyst. 9, Q11R05, doi:10.1029/2007GC001854.

Belopolsky, A., Tari, G., Craig, J., Iliffe, J., 2012. New and emerging plays in the Eastern Mediterranean: an introduction. Petrol. Geosci. 18, 371-372.

Berné, S., Rabineau, M., Flores, J.A., Sierro, F.J., 2004. The impact of Quaternary global changes on strata formation. Oceanography 17(4), 92-103.

Bertoni, C., Cartwright, J.A., 2006. Controls on the basinwide architecture of Messinian evaporites on the Levant margin (Eastern Mediterranean). Sediment. Geol. 188-189, 93114.

Bertoni, C., Cartwright, J.A., 2007a. Major erosion at the end of the Messinian SalinityCrisis: evidence from the Levant Basin, Eastern Mediterranean. Bas. Res. 19, 1-18. 
Bertoni, C., Cartwright, J.A., 2007b. Messinian (late Miocene) intra-evaporitic fans in the eastern Mediterranean: evidence from 3D seismic data. In: Schreiber, B.C., Lugli, S., Babel, M. (Eds.), Evaporites Through Space and Time. Geol. Soc. London Spec. Publ. $285,37-52$.

Bessis, F., 1986. Some remarks on the study of subsidence of sedimentary basins: application to the Gulf of Lions margin (Western Mediterranean). Mar. Petrol. Geol. 3, 37-63.

Biju-Duval, B., Letouzey, J., Montadert, L., 1978. Structure and evolution of the Mediterranean basins. In: Hsü K.J., Montadert L. et al., (Eds.), Leg 42 (1), Initial Reports of the Deep Sea Drilling Project, vol. 42(1), pp. 951-984.

Biju-Duval, B., Letouzey, J., Montadert, L., 1979. Variety of margins and deep basins in the Mediterranean. Geologic and geophysical investigations of continental margins. AAPG Mem. 29, 293-317.

Birrel, S., Courtier, J., 1999. Structural analysis of 3D seismic data, using the correlation attribute: a case study - Carboniferous of the Southern North Sea (UK). In: Fleet, A.J., Boldy, S.A.R. (Eds.), Petroleum Geology of Northwestern Europe, Proceedings of the 5th Conference, pp. 789-797.

Blanc, P.-L., 2000. Of sills and straits: a quantitative assessment of the Messinian Salinity Crisis. Deep-Sea Research Part 1, Oceanogr. Res. Papers 47(8), 1429-1460.

Blanc, P.-L., 2006. Improved modelling of the Messinian Salinity Crisis and conceptual implication. Palaeogeogr. Palaeoclimatol. Palaeoecol. 238, 349-372.

Bowman, S.A., 2012. A comprehensive review of the Msc facies and their origins in the offshore Sirt Basin, Libya. Petrol. Geosci. 18, 457-469. 
Buchbinder B., Zilberman E., 1997. Sequence stratigraphy of Miocene-Pliocene carbonate_siliciclastic shelf deposits in the eastern Mediterranean Margin (Israel): effects of eustasy and tectonics, Sediment. Geol. 112, 7-32.

Cartwright, J.A., Jackson, M.P.A., 2008. Initiation of gravitational collapse of an evaporitic basin margin: the Messinian saline giant, Levant Basin, eastern Mediterranean. Geol. Soc. Amer. Bull. 120(3-4), 399-413.

Cartwright, J.A., Jackson, M.P.A., Higgins, S., Dooley, T., 2012. Strain partitioning in gravity-driven shortening of a thick, multilayered evaporite sequence. In: ed. Alsop, I, Salt Tectonics II, Geol. Soc. London Spec. Publ. 363, 449-470.

Catuneanu, O., Galloway, W. E., Kendall, C. G. S. C., Miall, A. D., Posamentier, H. W., Strasser, A., \& Tucker, M. E. (2011). Sequence stratigraphy: methodology and nomenclature. Newsletters on Stratigraphy, 44(3), 173-245.

Chbat, W.E., Brahami, J. , Cherel, L., Dupin, I. Lucet,Y. and Montadert, L. Potential stratigraphic Traps in the Levant Basin (Offshore Lebanon)- 20142014 LIPE \& AAPG Northern Arabia Geoscience Conference and Exhibition 27-29 May 2014 Beirut (Lebanon).

Chumakov, I.S., 1973. Pliocene and Pleistocene deposits of the Nile Valley in Nubia and Upper Egypt. In: Ryan, W.B.F., Hsü, K.J. (Eds.), Leg 13. Initial Reports of the Deep Sea Drilling Project, vol.13(1), pp. 1242-1243.

CIESM, Antón, J., Çağatay, M.N., De Lange, G., Flecker, R., Gaullier, V., GundeCimerman, N., Hübscher, C., Krijgsman, W., Lambregts, P., Lofi, J., Lugli, S., Manzi, V., McGenity, T.J., Roveri, M., Sierro, F.J., Suc, J.-P., 2008. Executive summary. In: Briand, F. (Ed.), The Messinian Salinity Crisis from Mega-deposits to Microbiology e a Consensus Report, CIESM Workshop Monographs 33, 7-28. 
Cita, M.B., 1973. Mediterranean evaporite: paleontological arguments for a deep-basin desiccation model. In: Drooger, D.W. (Ed.), Messinian Events in the Mediterranean. North Holland Publishing Company, Amsterdam, London, pp. 206-228.

Clauzon, G., 1973. The eustatic hypothesis and the pre-Pliocene cutting of the Rhône valley. In: Ryan, W.B.F., Hsü, K.J. (Eds.), Leg 13. Initial Reports of the Deep Sea Drilling Project, 13(1), pp. 1251-1256.

Clauzon, G., 1978. The Messinian Var canyon (Provence, Southern France). Paleogeographic implications. Mar. Geol. 27(3-4), 231-246.

Clauzon, G., 1982. Le canyon messinien du Rhone, une preuve décisive du "desiccated deepbasin model” (Hsü, Cita et Ryan, 1973). Bull. Soc. Géol. France 24, 597-610.

Colin, C., Siani, G., Liu, Z.,Blamart, D., Skonieczny, C., Zhao, Y., Bory, A., Frank,N., Duchamp-Alphonse, S.,Thil, F., Richter, T., Kissel, C., Gargani, J., 2014: Late Miocene to early Pliocene climate variability off NW Africa (ODP Site 659), Palaeogeogr. Palaeoclimatol. Palaeoecol. 401, 81-95.

Denizot, G., 1952. Le Pliocène dans la vallée du Rhône. Rev. Géogr. Lyon 27(4), 327-357.

Druckman, Y., Buchbinder, B., Martinotti, G.M., Tov, R.S., Aharon, P., 1995. The buried Afiq Canyon (eastern Mediterranean, Israel): a case study of a Tertiary submarine canyon exposed in Late Messinian times. Mar. Geol. 123, 167-185.

Dümmong, S., Hübscher, C., 2011. Levant Basin - regional setting. In: Lofi, J., Déverchère, J., Gaullier, V., Gillet, H., Gorini, C., Guennoc, P., Loncke, L., Maillard, A., Sage, F., Thinon, I. (Eds.), Seismic Atlas of the "Messinian Salinity Crisis" Markers in the Mediterranean and Black Seas. Commission for the Geological Map of the World and Mémoires de la Société Géologique de France, Nouvelle Série, p. 57.

Duvail, C., Gorini, C., Lofi, J., Le Strat, P., Clauzon, G., dos Reis, A.T., 2005. Correlation 
between onshore and offshore Pliocene-Quaternary systems tract below the Roussillon Basin (eastern Pyrenees, France). Mar. Petrol. Geol. 22(6), 747-756.

Escutia, C., Maldonado, A., 1992. Paleoceanographic implications of the Messinian surface in the Valencia Trough, northwestern Mediterranean Sea. Tectonophysics 203, 263-284.

Esteban, M., Braga, J.C., Martín, J.M. and Santisteban, C., 1996. Western Mediterranean reef complexes. In: Models for Carbonate Stratigraphy from Miocene Reef Complexes of Mediterranean Regions (E. K. Franseen et al., eds), Concepts in Sedimentology and Paleontology 5, pp. 55-72.

Estrada, F., Ercilla, G., Gorini, C., Alonso, B., Vazquez, J., Garcia-Castellanos, D., Juan, C., Maldonado, A., Ammar, A., Elabbassi, M., 2011. Impact of pulsed Atlantic water inflow into the Alboran Basin at the time of the Zanclean flooding. Geo-Marine Letters 31, 361376.

Gamboa, L.A., 2004. The South Atlantic Aptian evaporitic sequence in the deep water areas of the Santos Basin. 32nd Int. Geol. Congr., 1(85-3), p. 417.

Garcia-Castellanos, D., Estrada, F., Jimenez-Munt, I., Gorini, C., Fernandez, M., Verges, J., De Vicente, R., 2009. Catastrophic flood of the Mediterranean after the Messinian salinity crisis. Nature $462,778-781$.

Garcia, M., Maillard, A., Aslanian, D., Rabineau, M., Alonso, B., Gorini, C., Estrada, F., 2011. The Catalan margin during the Messinian Salinity Crisis: physiography, morphology and sedimentary record. Mar. Geol. 284, 158-174.

Gardosh, M., Druckman, Y., Buchbinder, B., Rybakov, M., 2008. The Levant Basin offshoreIsrael: stratigraphy, structure, tectonic evolution and implications for hydrocarbon exploration - revised edition. Geological Survey of Israel Report GSI/4/ 2008, 1-119. 
Garfunkel, Z., Almagor, G., 1987. Active salt dome development in the Levant basin, southeast Mediterranean. In: Lerche, I., O'Brien, J., (Eds.), Dynamical Geology of Salt and Related Structures. Academic Press, London, pp. 263-300.

Gargani, J., Rigollet, C., 2007. Mediterranean sea-level variations during Messinian Salinity Crisis. Geophys. Res. Lett. 35, L10405.

Gargani, J.,Moretti, I., Letouzey, J., 2008. Evaporite accumulation during theMessinian Salinity Crisis: the Suez rift case. Geophys. Res. Lett. 35, L02401.

Gargani, J. Bache, F. Jouannic, G. Gorini, C., 2014. Slope Destabilization during the Messinian Salinity Crisis, Geomorphology 213, 128-138

Gaullier, V., Chanier, F., Lymer, G., Vendeville, B., Maillard, A., Thinon, I., Lofi, J., Sage, F., Loncke, L., 2014. Salt tectonics and crustal tectonics along the Eastern Sardinian margin, Western Tyrrhenian: New insights from the «METYSS 1» cruise. Tectonophysics 615-616, 68-84.

Geletti, R, Zgur F., Del Ben, A., Buriola, F., Fais, S., Fedi, M., Forte, E., Mocnik, A., Paoletti, V., Pipan, M., Ramella, R., Romeo, R., Romi, A., 2014. The Messinian Salinity Crisis: New seismic evidence in the West-Sardinian Margin and Eastern Sardo-Provençal basin (West Mediterranean Sea). Mar. Geol. 351, 76-90.

Ghielmi, M., Minervini, M., Nini, C., Rogledi, S., Rossi, M., Vignolo, A., 2010. Sedimentary and tectonic evolution in the eastern Po-Plain and northern Adriatic Sea area from Messinian to Middle Pleistocene (Italy). Rendic. Sci. Fis. Nat. Acad. Lincei 21, 131-166.

Gorini, C., Lofi, J., Duvail, C., Dos Reis, A. T., Guennoc, P., Lestrat, P., Mauffret, A., 2005. The Late Messinian salinity crisis and Late Miocene tectonism: interaction and consequences on the physiography and post-rift evolution of the Gulf of Lions margin. Marine and Petroleum Geology 22(6), 695-712. 
Guennoc, P., Gorini, C., Mauffret, A., 2000. Histoire géologique du golfe du Lion et cartographie du rift oligo-aquitanien et de la surface messinienne (Geological history of the gulf of Lions: Oligo-Aquitanian rift and Messinian surface maps). Géol. France 3, $67-97$.

Guennoc, P., Réhault, J.P., Thinon, I., 2011. West-Corsica basin. In: Lofi, J., Déverchère, J., Gaullier, V., Gillet, H., Gorini, C., Guennoc, P., Loncke, L., Maillard, A., Sage, F., Thinon, I. (Eds.), Seismic Atlas of the "Messinian Salinity Crisis" Markers in the Mediterranean and Black Seas. Commission for the Geological Map of the World and Mémoires de la Société Géologique de France, Nouvelle Série, pp. 48-49.

Gvirtzman, G., Buchbinder, B., 1978. The Late Tertiary of the Coastal Plain and continental shelf of Israel and its bearing of the history of the Eastern Mediterranean. In: Ross, D. H., Neprochnov, Y. P. (Eds.), Leg 42. Initial Reports of the Deep Sea Drilling Project. US Government Printing Office, Washington, pp. 1195-1222.

Gvirtzman, Z., Reshef,M., Buch-Leviatan, O., Ben-Avraham, B., 2013. Intense salt deformation in the Levant Basin in themiddle of the Messinian Salinity Crisis. Earth Planet. Sci. Lett. 379, 108-119.

Hardie, L.A., Lowenstein, T.K., 2004. Did the Mediterranean Sea dry out during the Miocene? A reassessment of the evaporite evidence from DSDP Legs 13 and 42A cores. Journ. Sedim. Res. 74, 453-461.

Hawie, N., Deschamps, R., Nader, F.H., Gorini, C., Müller, C., Desmares, D., Hoteit, A., Granjeon, D., Montadert, L., Baudin, F., 2013a. Sedimentological and stratigraphic evolution of northern Lebanon since the Late Cretaceous: implications for the Levant margin and basin. Arabian Journ. Geosci. 27 pp. doi 10.1007/s12517-013-0914-5.

Hawie, N., Gorini, C., Deschamps, R., Nader, F., H. Montadert, L., Granjeon, D., Baudin, F., 
2013b. Tectono-stratigraphic evolution of the northern Levant Basin (offshore Lebanon). Mar. Petrol. Geol. 48, 392-410.

Hsü, K.J., Cita, M.B., Ryan, W.B.F., 1973a. The origin of the Mediterranean evaporites. In: Kaneps, A.G. (Ed.), Leg 13. Initial Reports of the Deep Sea Drilling Project, vol. 13(2), pp. 1203-1231.

Hsü, K.J., Ryan, W.B.F., Cita, M.B., 1973b. Late Miocene desiccation of the Mediterranean. Nature 242, 240-244.

Hsü, K.J., Montadert, L., Bernoulli, D., Bizon, G., Cita, M., Erickson, A., Fabricius, F., Garrison, R.E., Kidd, R.B., Mélière, F., Müller, C., Wright, R.C., 1978a. In: Ross, D.A., Neprochnov, Y.P. (Eds.), Leg. 42. Initial Reports of the Deep Sea Drilling Project, vol 42(1), pp. 943-950.

Hübscher, C., Netzeband, G., 2007. Evolution of a young salt giant: the example of the Messinian evaporites in the Levantine Basin. In: Wallner, M., Lux, K.-H., Minkley, W., Hardy, J., H.R. (Eds.), The Mechanical Behaviour of Salt — Understanding of THMC Processes in Salt. Taylor\& Francis Group, London, p. 175-184.

Hübscher, C., Beitz, M., Dümmong, S., Gradmann, S., Meier, K., Netzeband, G.L., 2008. Stratigraphy, fluid dynamics and structural evolution of the Messinian evaporites in the Levantine Basin, Eastern Mediterranean. In: Briand, F. (Ed.), CIESM 2008. The Messinian Salinity Crisis from mega deposits to microbiology - A consensus report. CIESM Workshop Monographs 33, 97-106.

Hübscher, C., Dümmong, S., 2011. Levant Basin - salt and fluid dynamic. In: J.L., Déverchère, J., Gaullier, V., Gillet, H., Guennoc, P., Gorini, C., Loncke, L., Maillard, A., Sage, F., Thinon, I. (Eds.), Seismic Atlas of the "Messinian Salinity Crisis" Markers in the Mediterranean and Black Seas. Commission for the Geological Map of the World and 
Mémoires de la Société Géologique de France, nouvelle série, p. 60.

Hunt, D., Tucker, M.E., 1992. Stranded parasequences and the forced regressive wedge systems tract: deposition during base-level fall. Sedimentary Geology 81, 1-9.

Jolivet, L., Augier, R., Robin, C., Suc, J.-P. \& Rouchy, J.M., 2006. Lithospheric-scale geodynamic context of the Messinian salinity crisis. Sedim. Geol., 188-189, 9-33.

Kastens K.A., Mascle J., et al. (Eds.), 1987. Leg 107. Proceedings of the Ocean Drilling Program, Initial Reports. 107: College Station, TX.doi:10.2973/odp.proc.ir.107.1987.

Kertznus, V., Kneller, B., 2009. Clinoform quantification for assessing the effects of external forcing on continental margin development. Bas. Res. 21, 738-758.

Leroux, E., 2012. Quantifications des flux sédimentaires et de la subsidence dans le bassin Provençal, Mediterranée Occidentale (PhD Thesis). Université de Bretagne Occidentale, Brest, p. 455.

Leroux, E., Rabineau, M., Aslanian, D., Granjeon, D., Gorini, C., Droz, L., 2014. Stratigraphic simulation on the shelf of the gulf of lion: testing subsidence rates and sealevel curves during pliocene and quaternary. Terra Nova 26, 230-238.

Lofi, J., Rabineau, M., Gorini, C., Berne, S., Clauzon, G., De Clarens, P., Tadeu Dos Reis, A., Mountain, G.S., Ryan, W.B.F., Steckler, M.S., Fouchet, C., 2003. Plio-Quaternary prograding clinoform wedges of the western Gulf of Lion continental margin (NW Mediterranean) after the Messinian Salinity Crisis. Mar. Geol. 198, 289-317.

Lofi, J., Gorini, C., Berné, S., Clauzon, G., Tadeu Dos Reis, A., Ryan,W.B.F., Steckler,M., 2005. Erosional processes and paleo-environmental changes in the Western Gulf of Lions (SW France) during the Messinian Salinity Crisis. Mar. Geol. 217, 1-30.

Lofi, J., Berné, S., 2008. Evidence for pre-Messinian submarine canyons on the Gulf of Lions 
slope (Western Mediterranean). Mar. Petrol. Geol. 25, 804-817.

Lofi, J., Déverchère, J., Gaullier, V., Gillet, H., Gorini, C., Guennoc, P., Loncke, L., Maillard, A., Sage, F., Thinon, I., 2011a. Seismic atlas of the "Messinian Salinity Crisis" markers in the Mediterranean and Black seas. Commission for the Geological Map of the World and Memoires de la Société Géologique de France, Nouvelle Série, p. 72.

Lofi, J., Sage, F., Déverchère, J., Loncke, L., Maillard, A., Gaullier, V., Thinon, I., Gillet, H., Guennoc, P., Gorini, C., 2011b. Refining our knowledge of the Messinian salinity crisis records in the offshore domain through multi-site seismic analysis. Bull. Soc. Géol. France 182, 163-180.

Lofi J., Berné S., Tesson M., Séranne M., Pezard P., 2012. Giant solution-subsidence structure in the Western Mediterranean related to deep substratum dissolution. Terra Nova 24, 181-188.

Loncke, L., 2002. Le delta profond du Nil: structure et evolution depuis le Messinien (Miocene terminal), PhD thesis. University of Pierre et Marie Curie, Paris 6, pp 184

Loncke, L., Gaullier, V., Mascle, J., Vendeville, B., Camera, L., 2006. The Nile deep-sea fan: An example of interacting sedimentation, salt tectonics, and inherited subsalt paleotopographic features. Marine and Petroleum. Geology 23(3), 297-315.

Lugli, S., Gennari, R., Gvirtzman, Z., Manzi, V., Roveri, M., Schreiber, B.C., 2013. Evidence of clastic evaporites in the canyons of the Levant Basin (Israel): implications for the Messinian Salinity Crisis. Journ. Sedim. Res. 83, 942-954.

Maillard, A., Gorini, C., Mauffret, A., Sage, F., Lofi, J., Gaullier, V., 2006. Offshore evidence of polyphasic erosion in the Valencia Basin (Northwestern Mediterranean): scenario for the Messinian Salinity Crisis. Sediment. Geol. 188-189, 69-91. 
Maillard, A., Hübscher, C., Benkhelil, J., Tahchi, E., 2011. Deformed Messinian markers in the Cyprus Arc: tectonic and/or Messinian Salinity Crisis indicators? Bas. Res. 23, 146170.

Manzi, V., Gennari, R., Hilgen, F., Krijgsman, W., Lugli, S., Roveri, M., Sierro, F.J., 2013. Age refinement of the Messinian salinity crisis onset in the Mediterranean. Terra Nova $25,315-322$.

Mart, Y., Ben Gai, Y., 1982. Some depositional patterns at continental margin of southeastern Mediterranean Sea. Amer. Assoc. Petrol. Geol. Bull. 66, 460-470.

Mart, Y., 1982. Quaternary tectonic patterns along the continental margin of the southeastern Mediterranean. Mar. Geol. 49, 327-344.

Martín, J.M., Braga, J.C., Betzler, C., 2001. The Messinian Guadalhorce corridor: the last northern, Atlantic-Mediterranean gateway. Terra Nova, 13, 418-424, 200.

Mauffret, A., 1968. Etude des profils sismiques obtenus au cours de la campagne « Geomede 1 » au large des Baléares et dans la mer Ligure (Ph.D Thesis). Faculté des Sciences de Paris, p. 250.

Mauffret, A., Fail, J. P., Montadert, L., Sancho, J., Winnock, E., 1973. Northwestern Mediterranean sedimentary basin from seismic reflection profile: Am. Assoc. Petrol. Geol. Bull. 57, 2245-2262.

Meijer, P.Th., Krijgsman, W., 2005. A quantitative analysis of the desiccation and re-filling of the Mediterranean during the Messinian Salinity Crisis. Earth Planet. Sci. Lett. $\underline{240,}$ $510-520$.

Meijer, P.Th., 2006. A box model of the blocked-outflow scenario for the Messinian Salinity Crisis. Earth Planet. Sci. Lett. 248, 471-479. 
Montadert, L., Letouzey, J., Mauffret, A., 1978. Messinian event: seismic evidence. In: Hsü, K.J., Montadert, L., et al. (Eds.), Leg 42. Initial Reports of the Deep Sea Drilling Project, Vol. 42, part I., U.S. Govt. Printing Office, Washington, D.C., p. 1037-1050.

Montadert, L., Nicolaides, S., Semb, P.H.; Lie, Ø., 2014, Petroleum systems offshore Cyprus, in L. Marlow, C. Kendall and L. Yose, eds., Petroleum systems of the Tethyan region. Amer. Assoc. Petrol. Geol. Mem. 106, 301-334.

Netzeband, G.L., Hübscher, C.P., Gajewski, D., 2006. The structural evolution of the Messinian evaporites in the Levantine Basin. Mar. Geol. 230, 249-273.

Obone Zue Obame, E.M., Gaullier, V., Sage, F., Maillard, A., Lofi, J., Vendeville, B., Thinon, I., Réhault, J.-P., MAURESC Shipboard scientific party, 2011. The sedimentary markers of the Messinian salinity crisis and their relation with salt tectonics on the Provençal margin (western Mediterranean): results from the "MAURESC" cruise. Bull. Soc. Géol. France 183(2), 181-196.

Posamentier, H.W., Allen, G.P., 1999. Siliciclastic sequence stratigraphy: concepts and applications. SEPM Concepts in Sedimentology and Paleontology no.7, 210 pp.

Rabineau, M., Berné, S., Aslanian, D., Olivet, J.L., Joseph, P., Guillocheau, F., Bourillet, J.F., Ledrezen, E., Granjeon, D., 2005.Sedimentary sequences in the Gulf of Lion: A record of 100, 000 years climatic cycles. Mar. Petrol. Geol. 22, 775-804.

Rabineau, M., Berné , S., Olivet, J.-L., Aslanian, D., Guillocheau, F., Joseph, P., 2006. Paleo sea levels reconsidered from direct observation of paleoshoreline position during Glacial Maxima (for the last 500,000 yr). Earth Planet. Sci. Lett., 252, 119-137.

Rabineau, M., Leroux, E., Aslanian, D., Bache, F., Gorini, C., Moulin, M., Molliex, S., Droz, L., Reis, A.D., Rubino, J.-L., Guillocheau, F., Olivet, J.-L, 2014. Quantifying subsidence 
and isostatic readjustment using sedimentary paleomarkers, example from the Gulf of Lions. Earth Planet. Sci. Lett. 388, 1-14.

Reiche, S., Hübscher, C., Beitz, M. 2014. Fault-controlled evaporite deformation in the Levant Basin, Eastern Mediterranean. Mar. Geol. 354, 53-68.

Roveri, M., Bertini, A., Cosentino, D., Di Stefano, A., Gennari, R., Gliozzi, E., Grossi, F., Iaccarino, S.M., Lugli, S., Manzi, V., Taviani, M., 2008. A high-resolution stratigraphic framework for the latest Messinian events in the Mediterranean area. Stratigraphy 5, $323-342$.

Roveri, M., Flecker, R., Krijgsman, W., Lofi, J., Lugli, S., Manzi, V., Sierro, F.J., Bertini, A., Camerlenghi, A., De Lange, G.J., Govers, R., Hilgen, F.J., Hubscher, C., Meijer, P.Th., Stoica, M., 2014. The Messinian Salinity Crisis: past and future of a great challenge for marine sciences. Mar. Geol. 352, 25-58.

Ryan,W.B.F., Hsü, K.J., et al. (Eds.), 1973. Leg 13. Initial Reports of the Deep Sea Drilling Project, vol. 13, p. 1447.

Ryan, W.B.F., Hsü, K.J., scientific staff aboard Glomar Challenger for Leg 13, 1970. DeepSea Drilling Project: Leg 13. Geotimes 15(10), 12-15.

Ryan, W.B.F., 1973. Geodynamic implications of the Messinian crisis of salinity. In: Drooger, C.W. (Ed.), Messinian Events in the Mediterranean. North-Holland Publ. Co., Amsterdam, Netherlands, 26-38.

Ryan, W.B.F., 1976. Quantitative evaluation of the depth of the western Mediterranean before, during and after the late Miocene salinity crisis. Sedimentology 23(6), 791-813.

Ryan,W.B.F., 1978.Messinian badlands on the southeastern margin of the Mediterranean Sea. Mar. Geol. 27, 349-363.

Ryan,W.B.F., 2009. Decoding the Mediterranean salinity crisis. Sedimentology 56, 95-136. 
Ryan, W.B.F., Cita, M.B., 1978. The nature and distribution of Messinian erosion surfaces, indicators of a several kilometer- deep Mediterranean in the Miocene. Mar. Geol. 27, $193-230$.

Sage, F., Von Gronefeld, G., Deverchère, J., Gaullier, V., Maillard, A., Gorini, C., 2005. Seismic evidence for Messinian detrital deposits at the western Sardinia margin, northwestern Mediterranean. Mar. Petrol. Geol. 22, 757-773.

Sage, F., Déverchère, J., 2011. Northern Liguria. In: Lofi, J., Déverchère, J., Gaullier, V., Gillet, H., Gorini, C., Guennoc, P., Loncke, L., Maillard, A., Sage, F., Thinon, I. (Eds.), Seismic Atlas of the "Messinian Salinity Crisis" Markers in the Mediterranean and Black Seas. Commission for the Geological Map of the World and Memoires de la Société Géologique de France, Nouvelle Série, p. 42-44.

Savoye, B., Piper, D.J.W., 1991. The Messinian event on the margin of the Mediterranean Sea in the Nice area, southern France. Mar. Geol. 97, 279-304.

Schattner, U., Ben-Avraham, Z., Reshef, M., Bar-Am, G., and Lazar, M., 2006. OligoceneMiocene formation of the Haifa basin: Qishon-Sirhan rifting coeval with the Red SeaSuez rift System. Tectonophysics 419, 1-12.

Stampfli, G.M., Höcker, C.F.W., 1989. Messinian paleorelief from a 3-Dseismic survey in the Tarraco concession area (Spanish Mediterranean Sea). Geol. Mijnb. 68, 201-210.

Tassy A., Mocochain L., Bellier O., Braucher R., Gattacceca, J., Bourlès, D., 2013 Coupling cosmogenic dating and magnetostratigraphy to constrain the chronological evolution of peri-Mediterranean karsts during the Messinian and the Pliocene: Example of Ardèche Valley, Southern France, Geomorphology 189, 81-92

Tassy A., Fournier F., Munch P., Borgomano J., Thinon I., Fabri M.-C, Rabineau, M., Arfib, B., Begot, J., Beslier, M.-O., Cornée, J.-J., Fournillon, A., Gorini, C., Guennoc, P., Léonide, P., Oudet, J., Paquet, F., Sage, F., Toullec, R., 2014. Discovery of Messinian 
canyons and new seismic stratigraphic model, offshore Provence (SE France):

Implications for the hydrographic network reconstruction, Mar. Petrol. Geol. 57, 25-50.

Thinon, I., Réhault, J.P., Guennoc, P., 2011. East-Corsica basin. In: Lofi, J., Déverchère, J.,

Gaullier, V., Gillet, H., Gorini, C., Guennoc, P., Loncke, L., Maillard, A., Sage, F., Thinon, I. (Eds.), Seismic Atlas of the "Messinian Salinity Crisis" Markers in the Mediterranean and Black Seas. Commission for the Geological Map of the World and Memoires de la Société Géologique de France, Nouvelle Série, p. 45-47.

Tibor, G., Ben-Avraham, Z., Steckler, M., Fligelman, H., 1992. Late Tertiary subsidence history of the southern Levant margin, eastern Mediterranean Sea, and its implications to the understanding of the Messinian event, J. Geophys. Res. 97(B12), 17593-17614.

Urgeles, R., Camerlenghi, A., Garcia-Castellanos, D., De Mol, B., Garcés, M., Vergés, J., Haslam, I., Hardman, M, 2011. New constraints on the Messinian sealevel drawdown from 3D seismic data of the Ebro Margin, western Mediterranean. Bas. Res. 23, 123-145. Zahn, R., Comas, M.C., and Klaus, A. (Eds.), 1999. Proceedings of the Ocean Drilling Program, Scientific Results, Vol. 161

\section{Figure captions}

Fig. 1: Map showing the distribution of the Messinian salinity crisis (MSC) deposits in the deep and intermediate basins. "Deep basins" refers to their position in the deep central Messinian basins that are approximately delineated by the present-day Mediterranean slopes and abyssal plains around the Ligurian-Provencal basin (with a 30 Myr old basement) and the eastern basin (with an older Tethyan basement). The outlines of the Pliocene-Quaternary deep-sea fans of major Mediterranean rivers are indicated by dotted lines: the Rhone (1), the Ebro (2), the Nile (3), Levantine margin rivers (4), and Antalya margin rivers. In front of the Nile River, the Pliocene-Quaternary sediments and the Messinian clastics were sourced 
westward from the prominent Eratosthenes Continental Block (Montadert et al., 2014 modified). "Deep" IODP sites are located both in the eastern and western deep basins. This map is not palinspastically restored in its Messinian configuration, and some contours of the Messinian depocenters are consequently impacted by more recent tectonic episodes. The current locations of the main thrust fronts (Apennines, Calabrian wedge and Mediterranean Ridge) are indicated, as well as a tentative restoration of the active Messinian fronts (Apennines, Hellenides adapted from Jolivet et al., 2006). The eastern and western sub-basins were (and still are) located in distinct geodynamic environments: foreland flexure of a thick and cold lithosphere in the case of the eastern basin, back-arc basins impacted by thermal subsidence on a hot thin lithosphere in the case of the western Mediterranean and Tyrrhenian Basins. Early Messinian connections with the world ocean are in yellow (adapted from Esteban et al., 1996 and Martin et al., 2001).

Fig. 2: in Fig. 2b, Stratigraphic subdivisions of the MSC depositional Megasequence. Units $\mathrm{A}, \mathrm{B}$ and $\mathrm{C}$ are grouped as the Messinian lower megasequence (MLM) and sequences D and $\mathrm{E}$ are grouped as the Messinian upper megasequence (MUM). (For explanation see section 3 in the text. The position of the seismic line is shown in Fig. 2a). The nature of the high amplitude reflectors in the middle of the Messinian evaporites type section (Unit C) is debatable. Indeed few exploration wells in the southern Levant Basin crossed evaporites in the deep basin setting, and results have not been published. Nevertheless in offshore Lebanon (Chbat et al., 2014, Fig. 2b) stratigraphic inversion of seismic data and facies analysis is strong evidence that unit $\mathrm{C}$ consists of clastics, locally porous sands or claystones.

Fig. 3 Stratigraphic subdivisions of the MSC Messinian seismic megasequence. Compare with Fig. 2 MLM (sequences A, B and C). Note that laterally seismic facies change from high amplitude facies to transparent facies. (1) Messinian-Pliocene reworked evaporites and sands (see explanation in section 3 in the text); (2) Pliocene-Quaternary. Along the western part of 
the seismic lines (in the area shielded from river inputs) the same stratigraphic stacking can be seen as in Fig. 2. However both the Pliocene and pre-Messinian series are affected by high angle faults, or shallower gravitational listric faults, making stratigraphic interpretation challenging in this area (See comment in section 3.3 in the text).

Fig. 4: Seismic lines (Figs. 4b and 4c) located along the lower part of the Nile cone (Fig. 4a) reveal intercalation of a thick clastic unit $(\sim 2,000 \mathrm{~m})$ at the base of the MSC megasequence. The seismic facies of this unit corresponds to the MSC early lowstand distal deposits of the Nile River termed Messinian lower megasequence (MLM), in this paper. When seen in detail, the stacked channel complexes characterize this seismic facies. We interpret the highamplitude reflections in Units A, B and C in the halite toward the north of the line as clastic intercalations. The Messinian Nile River was the major source of clastic and meteoric waters to this area. We interpret these facies as turbidite deposits due to their distribution (see section 3 in the text for explanations). Note the alternation between clastics and salt suggested by the indentation between Messinian Nile clastics and the transparent halite. Post Messinian reverse faults can be seen in Fig. 4 b. Even if they are rooted in the Messinian salt, they may be associated with deeper duplexes that could generate the local doming on top of the MSC depositional megasequence visible in Figs. $4 \mathrm{a}$ and $4 \mathrm{~b}$.

Fig. 5: Seismic section of the Antalya Basin: This seismic profile shows the same stratigraphic stacking as in the Levant Basin (compare with Figs. 2 and 3). Continuous reflectors (Unit C) are visible between more transparent facies (Units B and D, we interpret as halite). Fig. 5 illustrates a large clastic body that laterally matches Units A, B and C, corresponding to the MLM, and Units D and E corresponding to MUM (see explanations in section 3 in the text). It is clear from these examples that choosing the base of the transparent layer (halite) as the base of the Messinian salinity crisis deposits would be misleading when dealing with big river systems. In this area reverse faults are visible. Doming and tilting of the 
Messinian clastics west of the line and layer $\mathrm{C}$ deformation east of the profile are controlled by compressional features (with a transport direction from the north).

Fig. 6: This figure is a comparison between the geometries and the seismic facies in the western and eastern Mediterranean in front of two major rivers: The Rhone River and the Nile River (see explanations in section 4 in the text). (1) Forced regressive Messinian deltas; (2) deep sea fans of the Rhone and Nile; (3) the Messinian seismic unit corresponding to units A, B and C in the Levantine Basin. Both (2) and (3) seismic units belong to the MLM; (4) the transition point. This point corresponds to the sharp transition between the MLM and MUM. It represents the lowest sea level in the Messinian megacycle. The mobile unit $(6$, halite) and the upper unit (7) were combined in the Messinian upper megasequence. MES: Messinian erosional surface; RS: ravinement surface; TES: Top erosional surface. The onset of the early transgression refers to a marine ravinement surface RS (flat abrasion surface, AS, after Bache et al., 2009). The mobile unit (unit 6, halite) ascribed to an increase in accommodation and aggradation (on-laps on the MES as it appears in the dataset) does not necessarily mean transgression but is linked with maximum regression (decrease in the rate of sea level fall).

Fig. 7: Line drawings (Figs. 7a and 7b, after Montadert et al., 1978) and seismic line (Figs. 7c, after Sage et al., 2011) showing the geometric relationships between the upper part of the MUM (7) and late lowstand fluvial conglomerates/ early transgressive marine sands ( $7^{\prime}$ ). Fig. 7c shows the seismic facies of the upper part of the MUM that onlaps the MES (1) all around the western Mediterranean. This unit was sampled by Savoye and Pipper (1991) across the Cirque Marcel and clearly infills the Messinien erosion surface (MES). Red conglomerates described by Savoye and Piper, 1991 at the base of these units are topped by Messinien marine sands. More recent seismic lines (Sage et al., 2011) show clear lateral continuity with 
the upper unit of Lofi et al., 2011 in the deep basin. These fluvial and coastal sediments illustrate the transition between a late Messinian lowstand onlapping the MES and an early transgressive systems tract (Early TST). In this area the forced regressive prisms are poorly imaged. (See explanations and comments in section 4.2, 4.3, and 5 in the text).

Fig. 8: Seismic line crossing Florence Ridge, west of the island of Cyprus. The thick evaporites of the MUM are clearly eroded, resulting in a flat surface (top erosional surface, TES) which can be confounded with Bottom Simulating Reflection (BSR).

Fig 9: Partial ground-truthing of the MUM: Site 372 on the eastern Menorca Rise (Fig. 9 a, Fig. 9 b, 2,699 m water depth) and the GLP2 industrial hole (Fig.9 c, 1,246 m water depth) sampled the upper part of the MUM evaporites (alternation of salt, gypsum beds and dolomitic marls) and the upper Miocene deposits. These evaporites cover the Messinian erosional surface on top of Serravalian marine siltstones (the Tortonian unit is absent). The location of the evaporites on top of the MES, probably re-eroded by a marine wave cut (flat abrasion surface), identifies the transgression of the upper part of MUM on the MES. This is consistent with the sparseness of sediments at the top of the MUM. Above these Messinian evaporites poor coring recovery hints at a potential sand layer at the transition to the early Pliocene. Site 371 in the South Balearic Basin (2,792 water depth, Fig. 1) recovered in situ anhydrite and dolomitic mudstone, on top of the MUM. Early Pliocene transgressive marine sands were recovered on top of this unit.

Fig. 9 c: The GLP2 borehole on the Gulf of Lion Margin (1,246 m water depth) revealed that Langhian-Serravalian age calcareous mudstones are overlain by 266 meters of alternating salt, calcareous evaporitic mudstones, and anhydrite (from 3,703 to 3,437 m) that are separated from the Upper Miocene by what we interpret as the MES. On top of the MUM evaporites, 52 $\mathrm{m}$ of transgressive marine sands (3385-3437m depth) were sampled, showing good aquifer reservoir quality. At the top of the MUM, we interpret the transition to seismic facies 
corresponding to the alternation of gypsum, salt and marls as the transition to an early transgression (ET) clearly illustrated by marine sands sampled in well GLP2 and linked to the flat marine abrasive surfaces (wave cut).

Fig. 10: Regional integrated model combining the western and eastern Mediterranean with the implicit notion that sedimentary development in the western and eastern basins happened in parallel (see discussion in section 5 in the text). PB peripheral basins; MTCs: Mass transport complexes; 1: forced regressive deltas; 2: deep basin clastics; 3: Lower Halite in the eastern basin (1 through 3 are included in the MLM); 4: Top of the MLM; 5: Mobile unit in the western basin (=Upper Halite in the eastern Basin); 6 Upper evaporites in the deep basin; 7a: fluvio-lacustrine sediments/ incised valley fill; 7b: Marine sands and conglomerates; 8: transgressive sands and reworked evaporites $(5,6,7,8$ are included in the MUM); 9a: Pliocene bottomsets with Globorotalia margaritae on the distal part of the platforms (condensed interval); 9b: Pliocene prograding clinoforms; 10: Pliocene deep sea fans; 11: Pliocene-Quaternary hemipelagic sediments; 12: Pliocene-Quaternary contourites. 


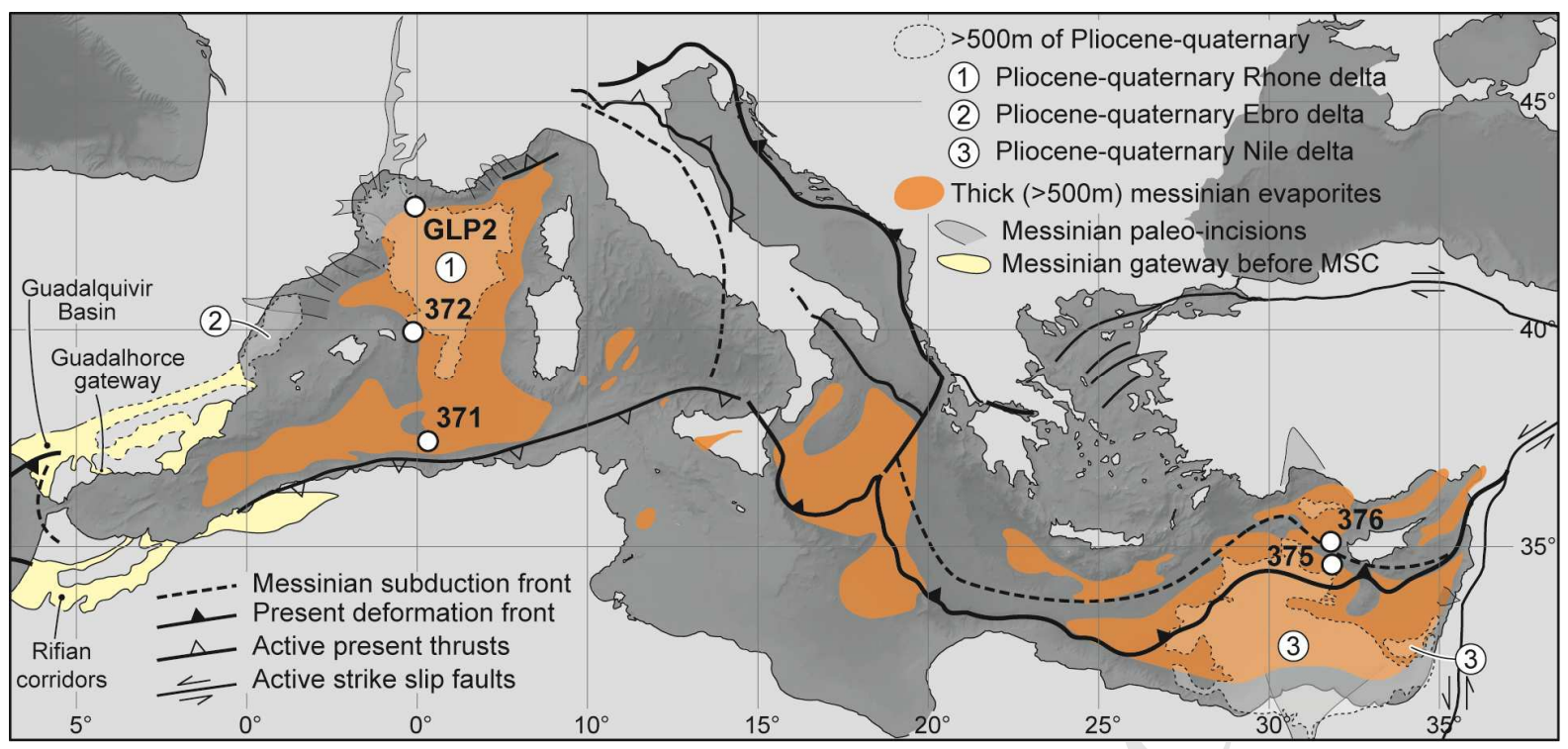


MUM Seismic Upper Messinian Upper Megasequence MLM Seismic Upper Messinian Lower Megasequence MSCM Messinian Salinity Crisis stratigraphic Megasequence

(A) (B) (C) (D) (E)

Levantine Basin type units (after Montadert et al. 2014)
Er. Eratosthenes

F. R. Florence Ridge

H. B. Herodotus Basin

\begin{tabular}{|l}
$\square$ Quaternary \\
$\square$ Tertiary \\
$\square$ Mesozoic \\
$\square$ Mesozoic-Trias \\
$\square \quad$ Permian/Trias \\
Paleozoic \\
Magmatic \\
Basic and ultra basic
\end{tabular}

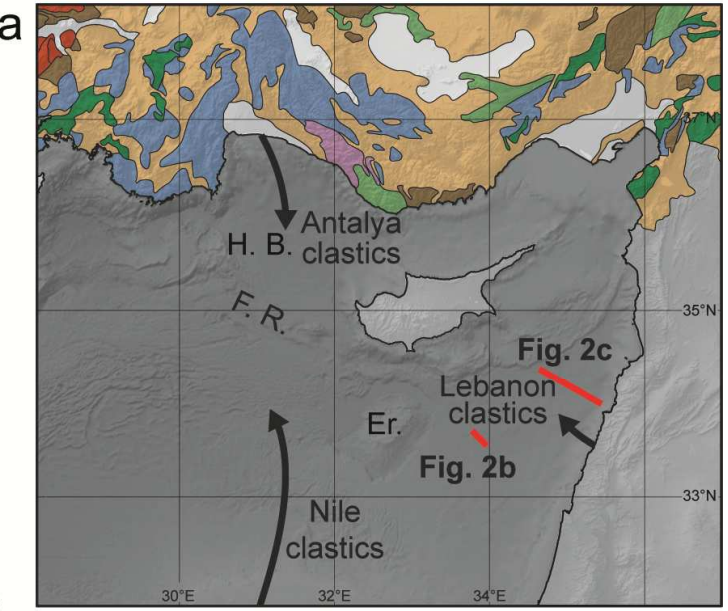

b

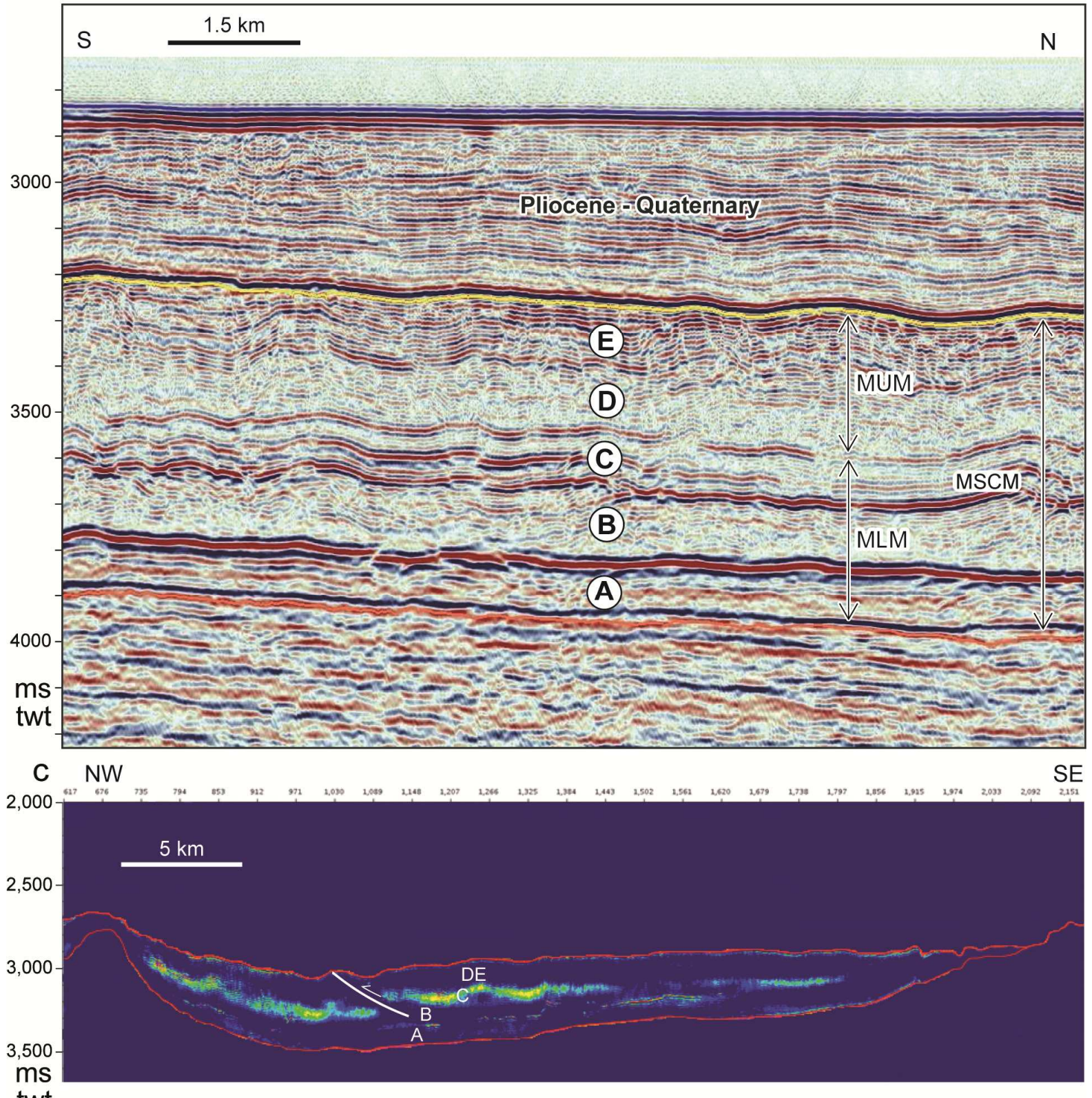

twt 
MUM Seismic Upper Messinian Upper Megasequence

MLM Seismic Upper Messinian Lower Megasequence MSCM Messinian Salinity Crisis stratigraphic Megasequence (A) (B) (C) (D) (E)

Levantine Basin type units (after Montadert et al. 2014)

Fault

Er. Eratosthenes

F. R. Florence Ridge H. B. Herodotus Basin

$\square$ Quaternary

$\square$ Tertiary

Mesozoic

Mesozoic-Trias

Permian/Trias

Paleozoic

Magmatic

Basic and ultra basic a

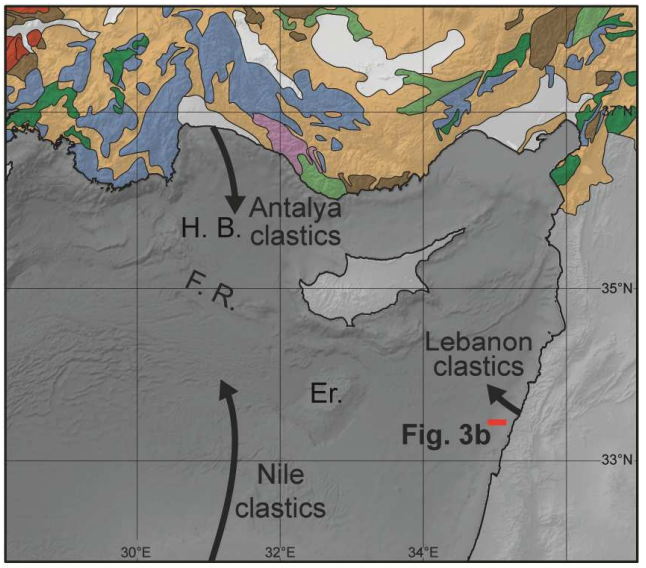

b

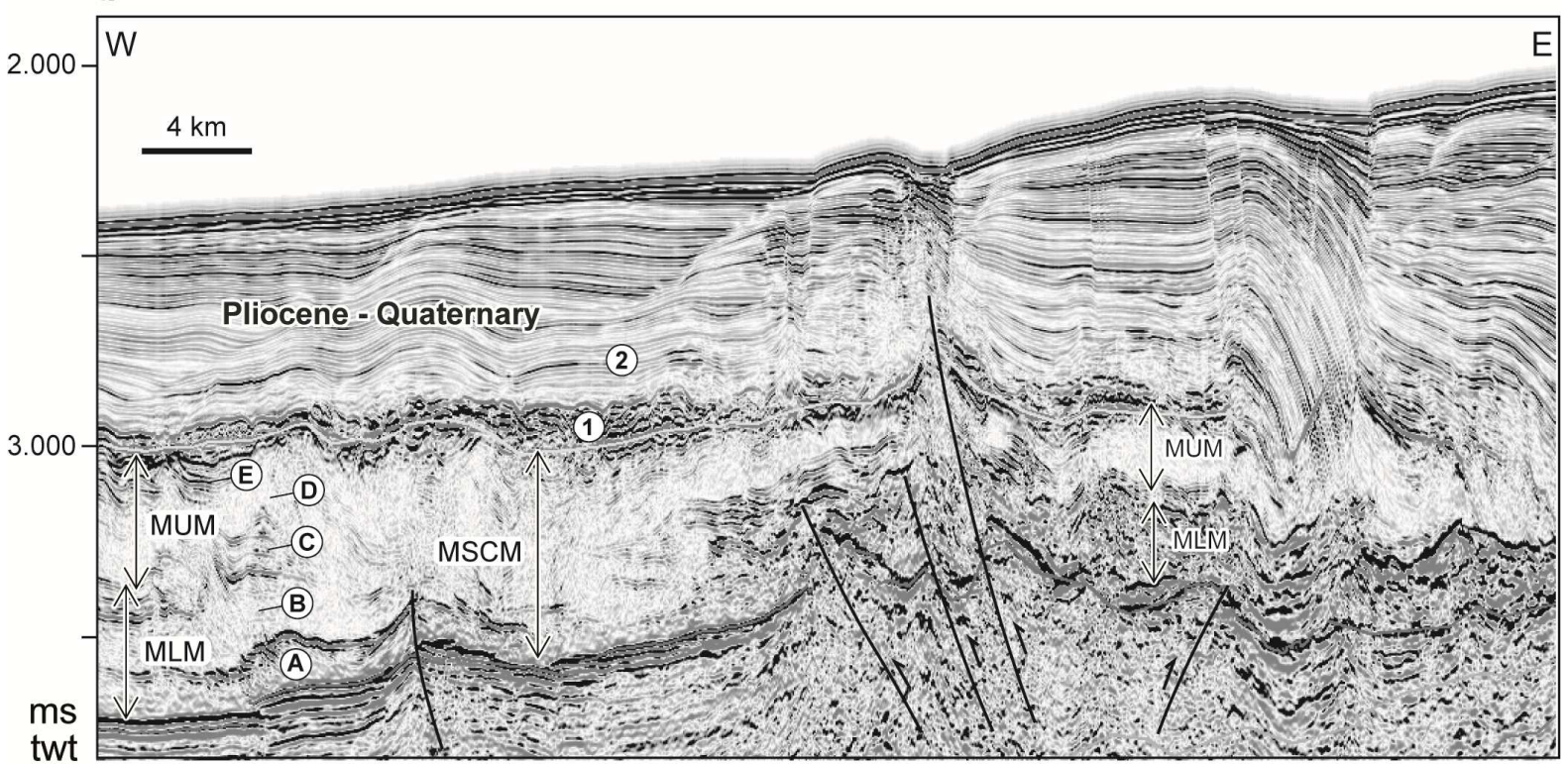




\section{ACCEPTED MANUSCRIPT}

MUM Seismic Messinian Upper Megasequence MLM Seismic Messinian Lower Megasequence MSCM Messinian Salinity Crisis stratigraphic Megasequence

(A) (B) (C) (D) (E)

Levantine Basin type units (after Montadert et al. 2014)

Er. Eratosthenes

F. R. Florence Ridge

H. B. Herodotus Basin

$\square$ Quaternary

$\square$ Tertiary

$\square$ Mesozoic

Mesozoic-Trias

Permian/Trias

Paleozoic

Magmatic

Basic and ultra basic

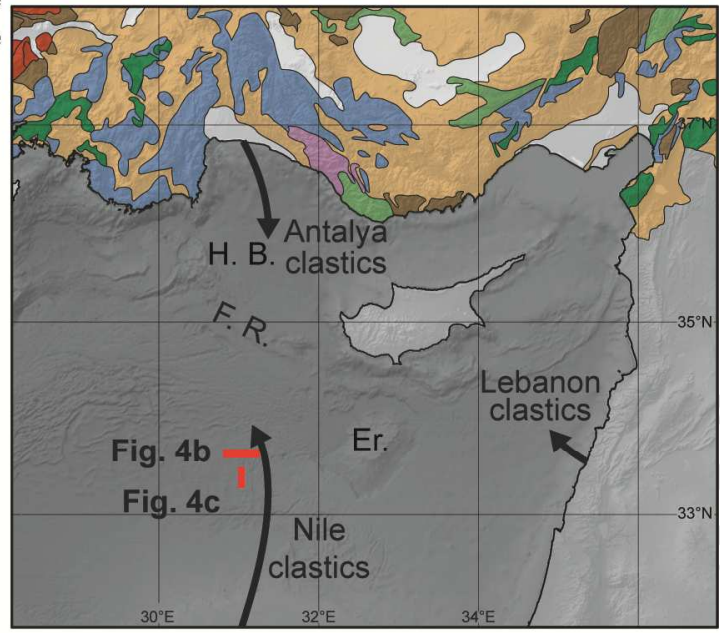

b

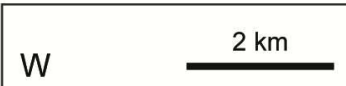

E

3500
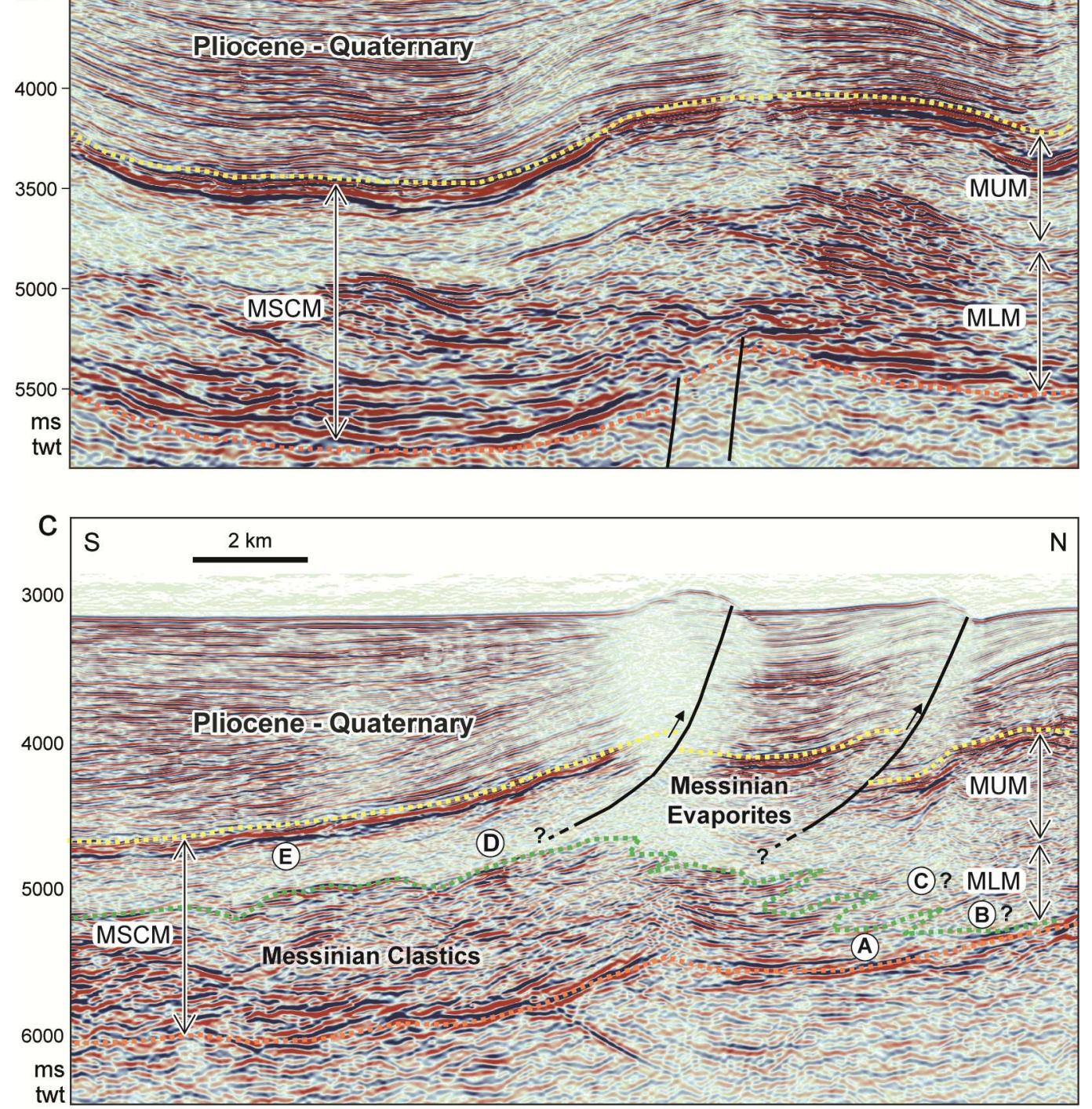
MUM Seismic Upper Messinian Upper Megasequence

MLM Seismic Upper Messinian Lower Megasequence

MSCM Messinian Salinity Crisis stratigraphic Megasequence

(A) (B) (C) (D) (E)

Levantine Basin type units

(after Montadert et al. 2014)

Reverse fault

Er. Eratosthenes

F. R. Florence Ridge

H. B. Herodotus Basin

a

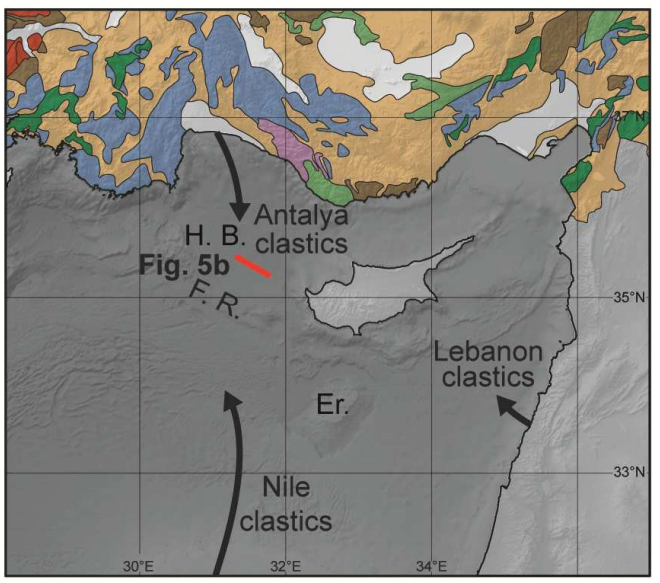

b

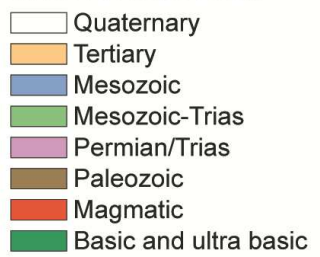

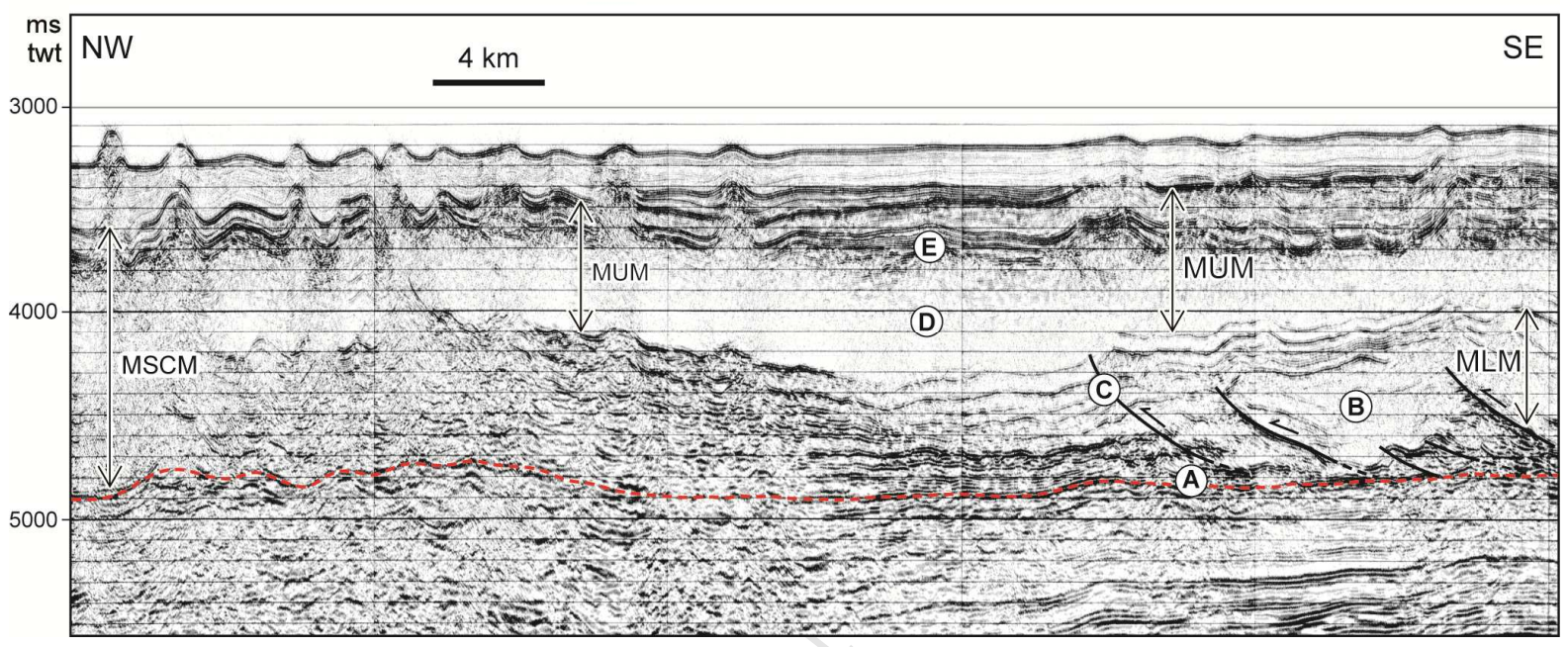



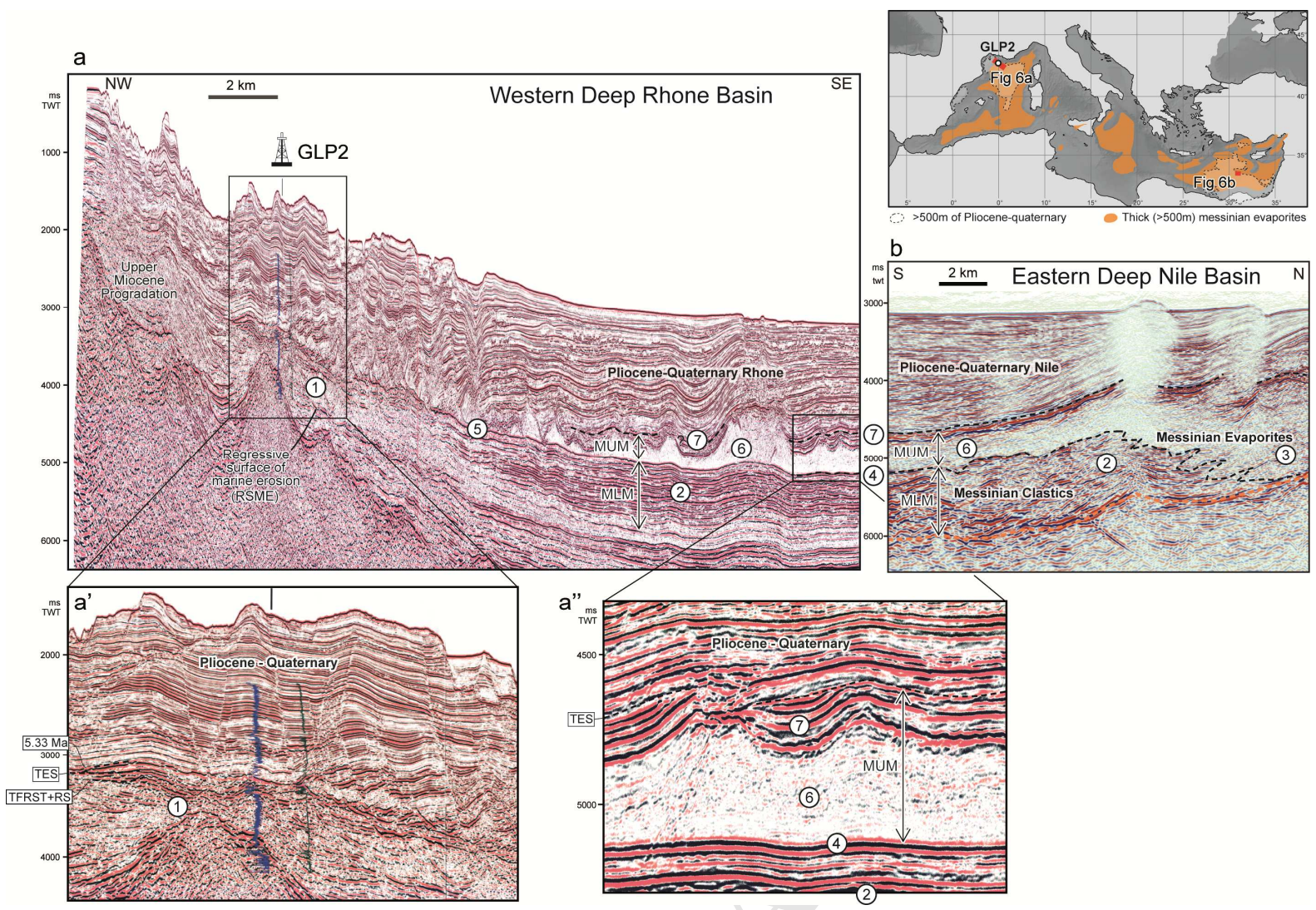

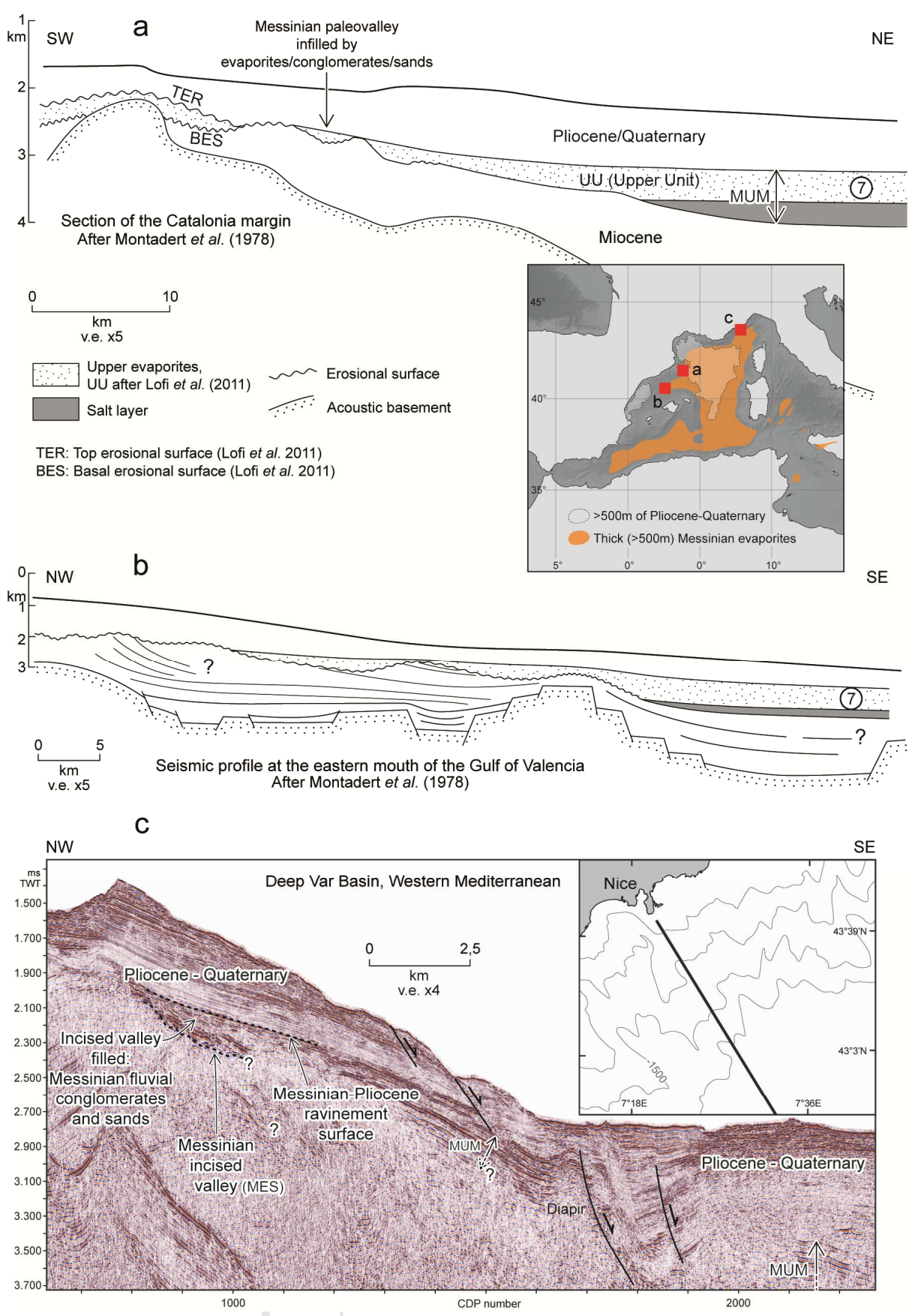
Er. Eratosthenes

F. R. Florence Ridge

H. B. Herodotus Basin

$\square$ Quaternary

$\square$ Tertiary

$\square$ Mesozoic

Mesozoic-Trias

$\square$ Permian/Trias

Paleozoic

Magmatic

Basic and ultra basic
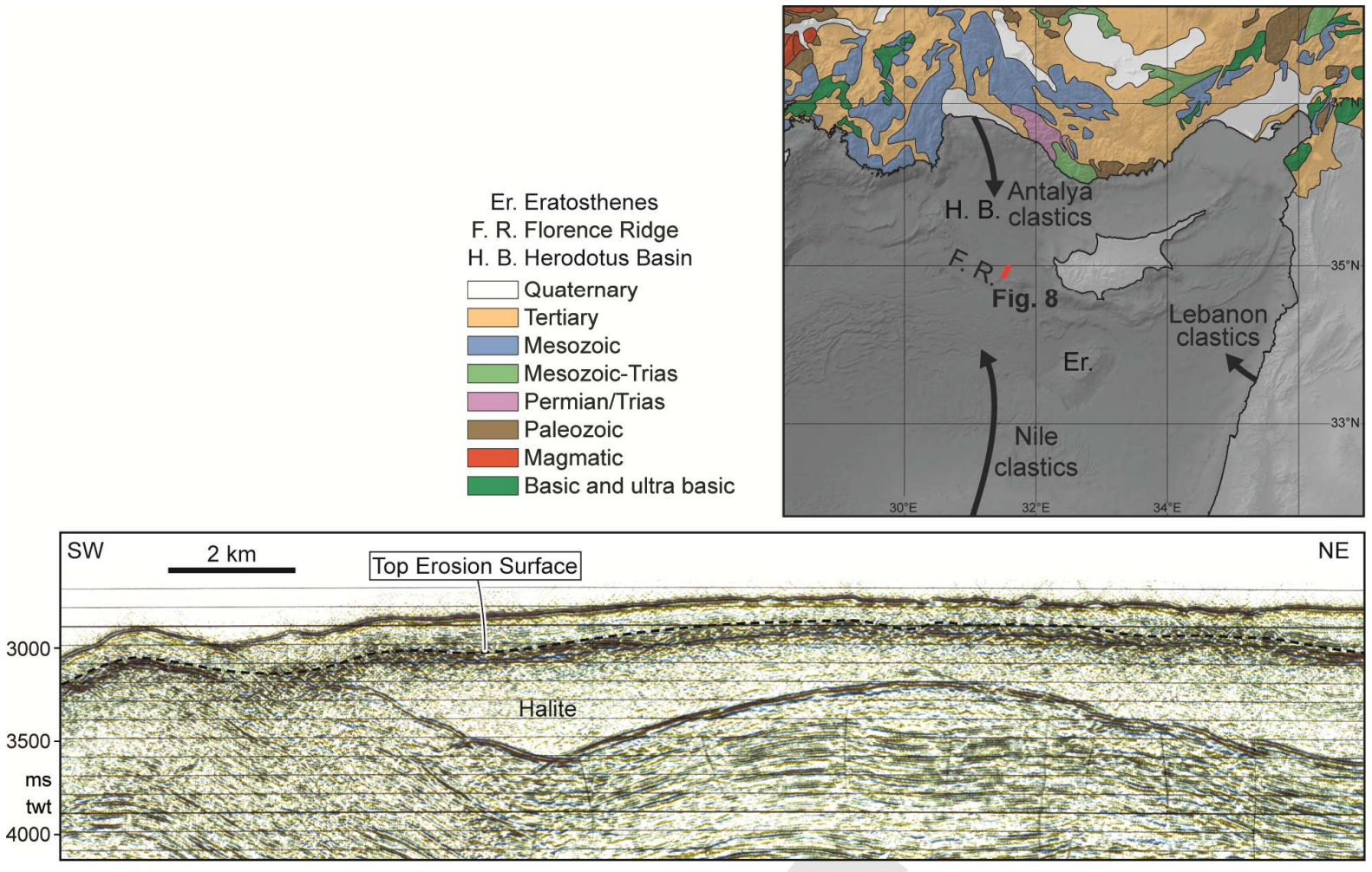

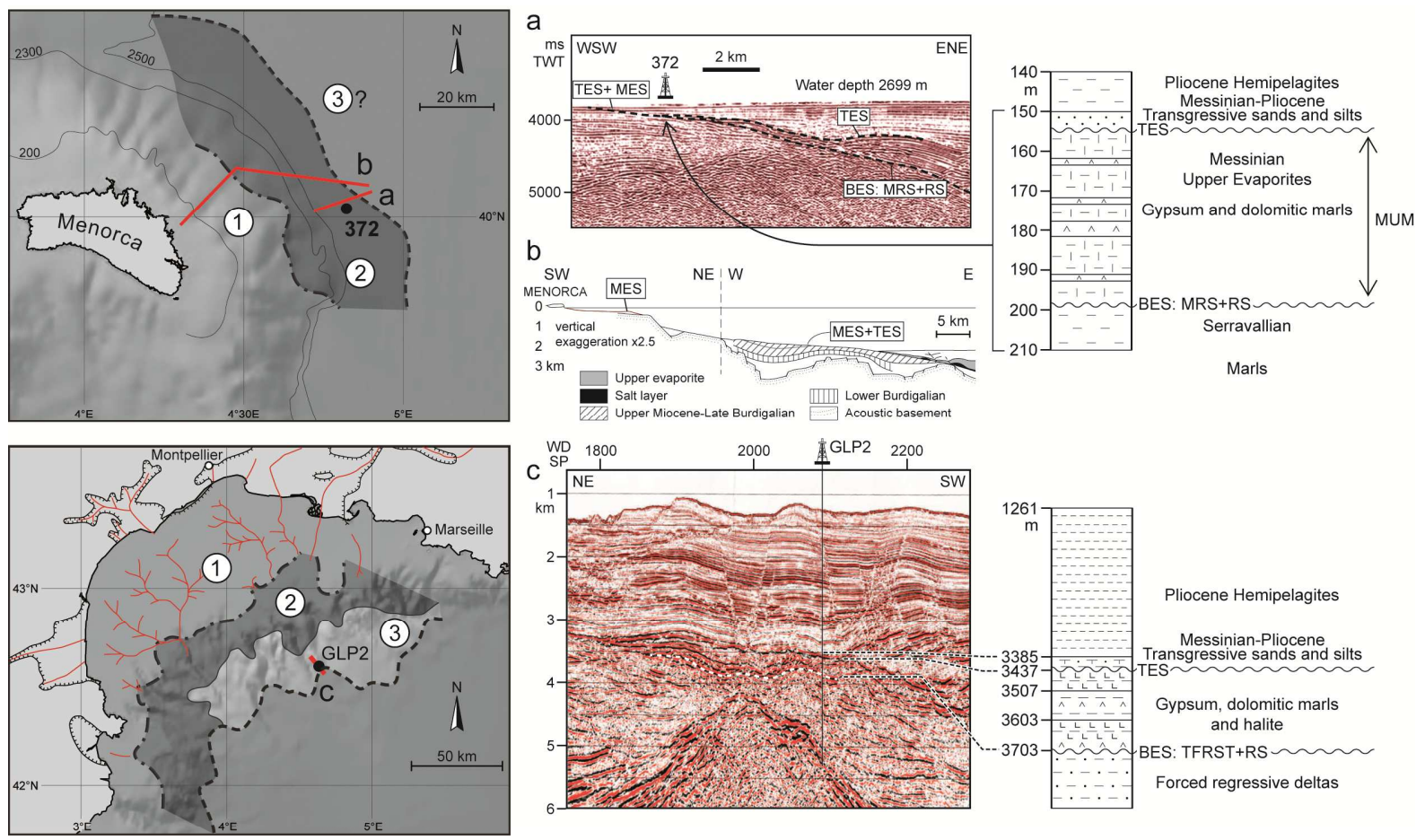

Pliocene Hemipelagites Messinian-Pliocene
Transgressive sands and silts Gypsum, dolomitic marls and halite BES: TFRST+RS

- Preserved inwised valley.

- - - - Thick salt layer pinch out. T Pliocene Gilbert delta area

(1) MES: Messinian erosional surface, preserved incised Messinian valleys (polyphased subareal erosional surface).

(2) TES: Last marine ravinement surface (this paper), top erosional surface (Lofi et al. 2011) (3) Transgressive sands and silts RS: Marine ravinement surface + MES MRS: Maximum regressive surface TFRST: Top of forced regressive systems tracts BES: Basal erosional surface (Lofi et al. 2011) 


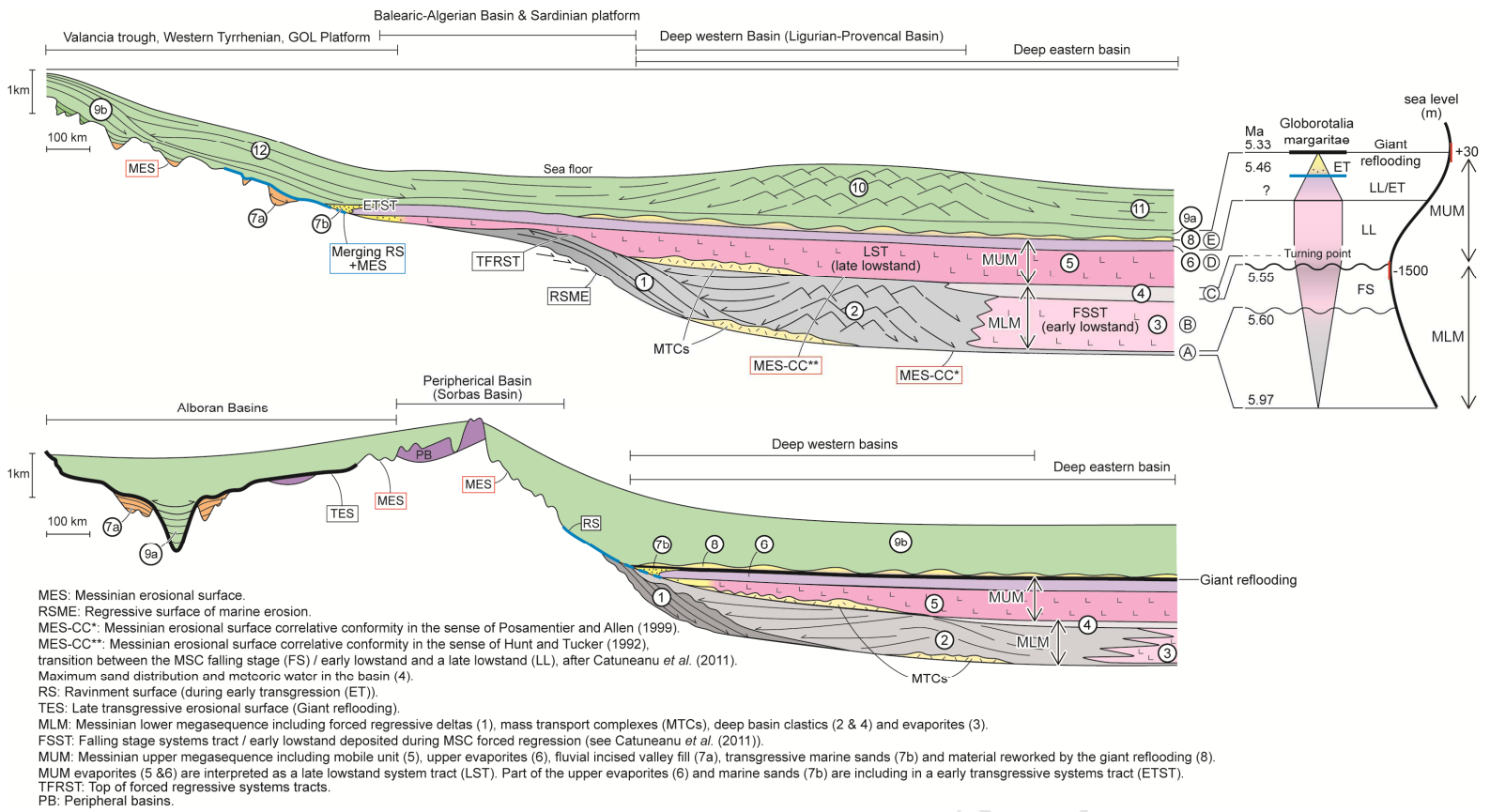




\section{Highlights:}

-New industrial seismic lines reveal the first full image of Messinian deposits;

-Efficient guideline to interpret the Messinian salinity crisis (MSC) megasequence.

- Major improvement in the understanding of the MSC.

-Critical west-east similarities led to a comprehensive MSC depositional model 